\title{
Current Status of Gene Engineering Cell Therapeutics
}

\author{
Aurore Saudemont ${ }^{*}$, Laurent Jespers ${ }^{1}$ and Timothy Clay ${ }^{2}$ \\ ${ }^{1}$ GlaxoSmithKline, Stevenage, United Kingdom, ${ }^{2}$ GlaxoSmithKline, Collegeville, PA, United States
}

Ex vivo manipulations of autologous patient's cells or gene-engineered cell therapeutics have allowed the development of cell and gene therapy approaches to treat otherwise incurable diseases. These modalities of personalized medicine have already shown great promises including product commercialization for some rare diseases. The transfer of a chimeric antigen receptor or $T$ cell receptor genes into autologous $T$ cells has led to very promising outcomes for some cancers, and particularly for hematological malignancies. In addition, gene-engineered cell therapeutics are also being explored to induce tolerance and regulate inflammation. Here, we review the latest gene-engineered cell therapeutic approaches being currently explored to induce an efficient immune response against cancer cells or viruses by engineering T cells, natural killer cells, gamma delta T cells, or cytokine-induced killer cells and to modulate inflammation using regulatory $T$ cells.

\section{OPEN ACCESS} Edited by:
Ulrike Koehl,
Hannover Medical School,

Germany

Reviewed by:

Reinhard Henschler,

Swiss Red Cross, Switzerland

Evelyn Ullrich,

Goethe University Frankfurt,

Germany

*Correspondence:

Aurore Saudemont

aurore.x.saudemont@gsk.com

Specialty section:

This article was submitted to Alloimmunity

and Transplantation,

a section of the journal

Frontiers in Immunology

Received: 21 September 2017

Accepted: 17 January 2018

Published: 05 February 2018

Citation:

Saudemont A, Jespers $L$ and Clay $T$ (2018) Current Status of Gene Engineering Cell Therapeutics.

Front. Immunol. 9:153. doi: 10.3389/fimmu.2018.00153
Keywords: cell therapy, gene therapy, autologous, allogeneic, ex vivo therapy

\section{INTRODUCTION}

Cell and gene therapy is an emerging field with the high potential to offer a curative therapy. Gene therapy is defined as the use of genetic material such as DNA to manipulate a patient's cells, and cell therapy is defined as the administration of live whole cells or of a specific cell population to a patient. In many diseases, cell and gene therapies are combined as gene engineering cell therapeutics in the development of promising therapies for the treatment of an acquired or inherited disease. The number of applications for gene engineering cell therapeutics is increasing at a very rapid pace, with these applications being at different development stages from preclinical to clinical.

Autologous gene engineering cell therapeutics have the potential to correct the underlying genetic cause of some monogenic disorders and potentiate immune responses against cancers to provide sustained clinical responses (1-5). In addition, one of the main advantages of autologous therapies is their full major histocompatibility complex (MHC) compatibility leading to a better engraftment and persistence of the cells and a low risk of graft versus host disease (GvHD). Gene transfer into autologous hematopoietic stem cells (HSC) has shown potential especially in treating primary immunodeficiencies such as X-linked severe combined immunodeficiency (X-SCID) or adenosine deaminase deficiency-SCID. The transfer of a chimeric antigen receptor (CAR) or T cell receptor (TCR) genes into autologous $\mathrm{T}$ cells allows redirecting the genetically engineered $\mathrm{T}$ cells towards specific antigens expressed on cancer cells or presented as peptides on MHC molecules, respectively. In particular, the transfer of autologous CD19-CAR T cells in patients with hematological malignancies has been very successful, achieving impressive remission rates (6). Notably, the Food and Drug Administration (FDA) recently approved the first CAR T cell therapy, Kymriah ${ }^{\circledast}$ (or tisagenlecleucel), for patients with B cell acute lymphoblastic leukemia (ALL). In addition, another CAR therapy was approved by the FDA, "Yescarta ${ }^{\circledR}$ (axicabtagene ciloleucel), for the treatment of adult patients with certain types of non-Hodgkin lymphoma. 
However, some of the trials testing gene engineering cell therapeutics have not been without setbacks such as the incidence of insertional mutagenesis observed in the first clinical trials for X-SCID, which has led to the design of new vectors allowing reducing their potential for insertional mutagenesis. This also highlighted the clear need for long-term follow-up for the patients receiving these live gene engineering cell therapeutics. In addition, several deaths linked to neurotoxicity in patients treated with CD19-CAR T cells have been reported and the cytokines produced after infusion of the product can lead to adverse effects such as cytokine release syndrome (CRS) that many patients experienced, highlighting the fact that we still need to gain a better understanding of the effects of gene engineering cell therapeutics in patients so as to make these therapies safer. Here, we review the latest gene engineered cell therapeutic approaches being currently explored preclinically but emphasizing those that have been clinically tested (Figure 1), to induce an efficient immune response against cancer cells or viruses by engineering T cells, natural killer (NK) cells, gamma delta T cells or cytokineinduced killer (CIK) cells and to modulate inflammation by using regulatory T cells (Tregs).

\section{CELL AND GENE THERAPIES FOR ONCOLOGY}

Different cell types can be used to develop gene engineering cell therapeutics to induce an immune response against tumor cells.
Here, we will review the use of TCR- or CAR-modified T cells (TCR-T or CAR-T), NK cells, CIK cells, and gamma delta T cells for oncology.

\section{Autologous TCR-T and CAR-T}

$\mathrm{T}$ cell engineering provides the possibility to generate antigenspecific $\mathrm{T}$ cells for many types of cancer. The identification of a graft versus leukemia (GvL) effect and subsequent recognition that $\mathrm{T}$ cells played a role provided an early indicator of the potential of $\mathrm{T}$ cells to mediate antitumor effects and led to the use of donor lymphocyte infusion (DLI). Subsequent studies of autologous tumor infiltrating lymphocytes (TIL) in melanoma patients for whom suitable TIL could be isolated and expanded successfully, allowing adoptive transfer, led to significant clinical responses $(7,8)$. The difficulty to isolate TIL from some patients' tumors, especially with non-melanoma tumors, led to the concept of modifying autologous peripheral blood $\mathrm{T}$ cells to redirect them to recognize tumors offering an alternative approach to develop $\mathrm{T}$ cell therapies. Two principal strategies were developed, one using natural TCR that recognized human leukocyte antigen (HLA)-restricted tumor-associated antigen peptides (9-12) and the other seeking to use antibody recognition domains linked to TCR signaling molecules in CAR (13-15).

Both strategies have been continually refined over the last 15 years, with promising early data culminating in a number of medicines in late-stage clinical development and two approved medicines (Tables 1 and 2). The first clinical study of TCR-T
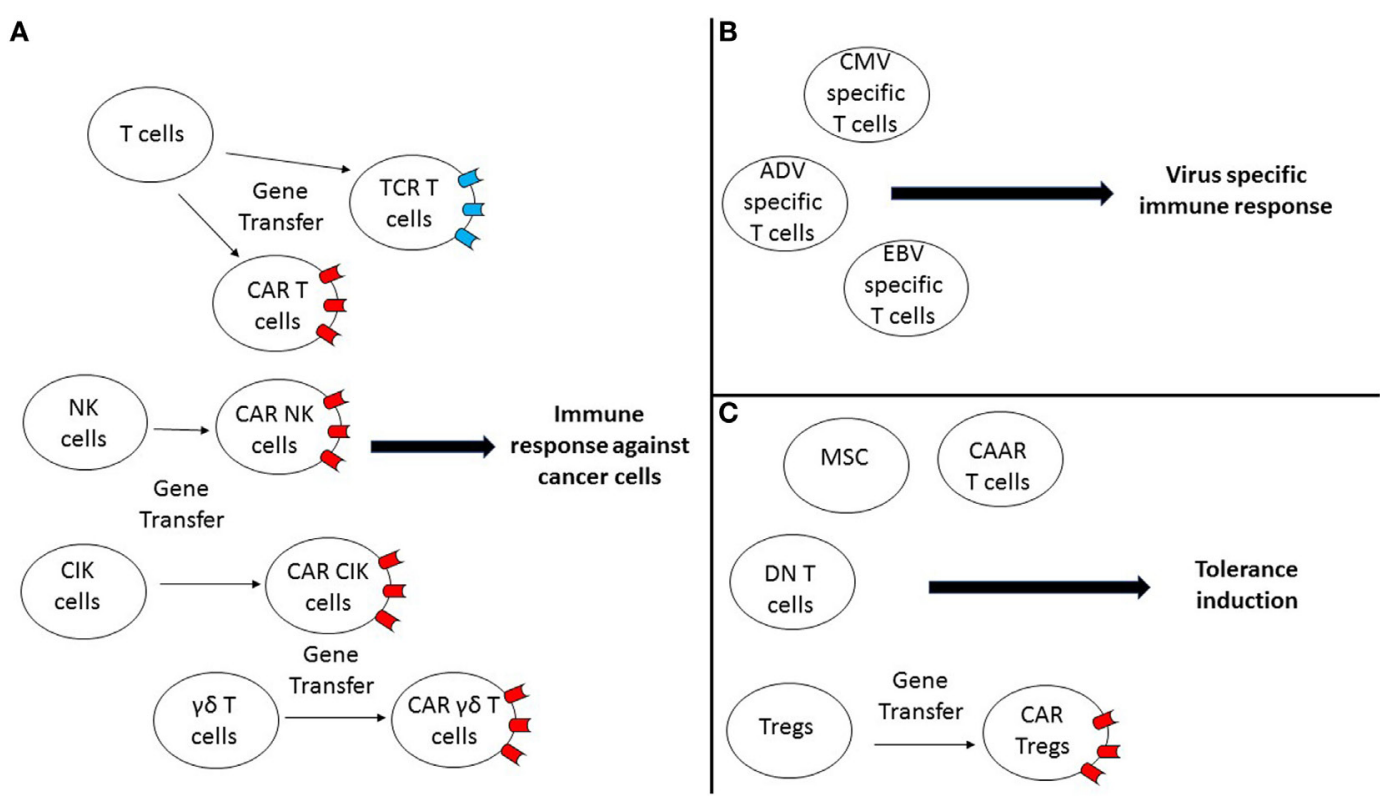

FIGURE 1 | Gene-engineered cell therapeutic approaches are currently explored preclinically and clinically to induce potent immunity against cancer, infection, or to induce tolerance. (A) Different gene-engineered cell therapeutic approaches using either T cells, natural killer (NK) cells, cytokine-induced killer (CIK) cells, or $\gamma \delta$ T cells are being explored to induce an efficient immune response against cancer cells. Notably, these different cell types can be reprogrammed by gene transfer of a T cell receptor (TCR) or a chimeric antigen receptor (CAR), so they can target efficiently specific antigens expressed by cancer cells. (B) Virus-specific T cells can be used as a cell therapy approach to restore virus-specific immunity in patients. (C) Different approaches are being explored to induce tolerance for different indications by either using mesenchymal stem cells (MSC), double negative (DN) T cells, CAR T cells, or regulatory T cells (Tregs)-based approaches or by explored manipulating Tregs (CAR-Tregs). 
TABLE 1 | Summary of key published clinical results of T cell receptor gene-modified T cell therapies.

\begin{tabular}{|c|c|c|c|c|c|c|}
\hline Reference & Center & $\begin{array}{l}\text { Clinicaltrials.gov } \\
\text { identifier }\end{array}$ & Product & Indication & Clinical outcome & Toxicity \\
\hline$(12)$ & $\mathrm{NCl}$ & $\begin{array}{l}\text { Phase I, approved by the } \\
\text { NIH IRB, NCI IRB, NIH RAC, } \\
\text { and FDA-CBER }\end{array}$ & $\begin{array}{l}\text { Autol. T cells with MART- } \\
\text { 1-specfic wild-type hTCR }\end{array}$ & Melanoma & PR 2/17 & No related toxicities \\
\hline$(16)$ & $\mathrm{NCl}$ & $\begin{array}{l}\text { Phase I, NCl-07-C-0174 } \\
\text { and NCl-07-C-0175 }\end{array}$ & $\begin{array}{l}\text { Autol. PB T cells with MART-1- } \\
\text { specific high-affinity hTCR }\end{array}$ & Melanoma & PR 6/20 & $\begin{array}{l}\text { Up to G2 skin, G2 eye, } \\
\text { and G3 ear toxicity }\end{array}$ \\
\hline (16) & $\mathrm{NCl}$ & $\begin{array}{l}\text { Phase I, NCl-07-C-0174 } \\
\text { and NCl-07-C-0175 }\end{array}$ & $\begin{array}{l}\text { Autol. T cells with gp100- } \\
\text { specific mTCR }\end{array}$ & Melanoma & CR 1/16, PR 2/16 & $\begin{array}{l}\text { Up to G2 skin, G2 eye, } \\
\text { and G3 ear }\end{array}$ \\
\hline (17) & $\mathrm{NCl}$ & $\begin{array}{l}\text { Phase I, approved by the } \\
\text { NIH IRB, NCI IRB, NIH RAC, } \\
\text { and FDA-CBER }\end{array}$ & $\begin{array}{l}\text { Autol. T cells with p53- } \\
\text { specific mTCR }\end{array}$ & $\begin{array}{l}\text { Various epithelial } \\
\text { cancers }\end{array}$ & PR 1/14 & \\
\hline (18) & $\mathrm{NCl}$ & Phase I, NCT00923806 & $\begin{array}{l}\text { Autol. T cells with CEA- } \\
\text { specific mTCR }\end{array}$ & Colorectal cancer & $\begin{array}{l}\text { PR 1/3, 3/3 with } \\
\text { decreased serum CEA } \\
\text { protein levels }\end{array}$ & $\begin{array}{l}\text { 3/3 developed transient } \\
\text { inflammatory colitis up } \\
\text { to G3 }\end{array}$ \\
\hline (19) & $\mathrm{NCl}$ & $\begin{array}{l}\text { Phase I, approved by the } \\
\text { NIH IRB, NCI IRB, NIH RAC, } \\
\text { and FDA-CBER }\end{array}$ & $\begin{array}{l}\text { Autol. T cells with NYESO1- } \\
\text { specific mTCR }\end{array}$ & $\begin{array}{l}\text { Melanoma and } \\
\text { synovial sarcoma }\end{array}$ & $\begin{array}{l}\text { Melanoma CR 2/11, PR } \\
\text { 3/11; synovial sarcoma } \\
\text { PR 4/6 }\end{array}$ & No related toxicity \\
\hline$(20)$ & $\mathrm{NCl}$ & Phase I, NCT01273181 & $\begin{array}{l}\text { Autol. T cells with } \\
\text { MAGEA3-specific mTCR }\end{array}$ & $\begin{array}{l}\text { Melanoma, } \\
\text { synovial sarcoma, } \\
\text { and esophageal } \\
\text { cancer }\end{array}$ & $\begin{array}{l}\text { Melanoma CR1/7, PR } \\
\text { 4/7; synovial carcinoma } \\
\text { 0/1; and esophageal } \\
\text { carcinoma NR 0/1 }\end{array}$ & $\begin{array}{l}3 \text { patients developed } \\
\text { mental disturbances and } \\
2 \text { died from necrotizing } \\
\text { leukoencephalopathy }\end{array}$ \\
\hline$(21)$ & UPenn & $\begin{array}{l}\text { Phase I, NCT01350401 } \\
\text { and NCT01352286 }\end{array}$ & $\begin{array}{l}\text { Autol. T cells with affinity- } \\
\text { enhanced NYESO1-specific hTCR }\end{array}$ & $\begin{array}{l}\text { Melanoma and } \\
\text { myeloma }\end{array}$ & & $\begin{array}{l}2 / 2 \text { patients died from } \\
\text { cardiogenic shock }\end{array}$ \\
\hline (22), & UCLA & Phase I, NCT00910650 & $\begin{array}{l}\text { Autol. T cells with affinity- } \\
\text { enhanced MART1-specific hTCR }\end{array}$ & Melanoma & $\begin{array}{l}\text { Short-term regression } \\
9 / 14\end{array}$ & $\begin{array}{l}2 \text { patients experienced } \\
\text { respiratory distress }\end{array}$ \\
\hline$(27)$ & MieU & $\begin{array}{l}\text { Phase I, UMIN Clinical } \\
\text { Trials Registry ID: } \\
\text { UMIN000002395 }\end{array}$ & $\begin{array}{l}\text { Autol. T cells with MAGEA4- } \\
\text { specific hTCR }\end{array}$ & $\begin{array}{l}\text { Esophageal } \\
\text { cancer }\end{array}$ & $\begin{array}{l}3 / 10 \text { patients who had } \\
\text { minimal tumor lesions } \\
\text { at baseline survived for } \\
>27 \text { months }\end{array}$ & No related toxicities \\
\hline (23) & UPenn & Phase I, NCT01352286 & $\begin{array}{l}\text { Autol. T cells with affinity- } \\
\text { enhanced NYESO1-specific hTCR }\end{array}$ & Multiple myeloma & $\begin{array}{l}\text { nCR or CR 14/20, vgPR } \\
\text { 2/20, PR 2/20, SD 1/20, } \\
\text { and PD 1/20 }\end{array}$ & $\begin{array}{l}\text { Grade } 3 \text { or lower AE's } \\
\text { included } 3 / 20 \text { with Gr } 3 \text { Gl } \\
\text { aGVHD, } 2 / 20 \text { with Gr2 skin } \\
\text { aGVHD }\end{array}$ \\
\hline
\end{tabular}

aGWV, acute graft versus host disease; Autol, autologous; CR, complete response; G2, grade 2; G3, grade 3; hTCR, human T cell receptor; MieU, Mie University; mTCR, murine $T$ cell receptor; $\mathrm{NCl}$, National Cancer Institute; $n C R$, near complete response (defined as myeloma monoclonal band detectable only by sensitive immunofixation assay); NR, no response; PD, progressive disease; PB, peripheral blood; Periph, peripheral; PR, partial response; SD, stable disease; UCLA, University of California Los Angeles; UPenn, University of Pennsylvania; vgPR, very good partial response (defined as $\geq 90 \%$ reduction in paraprotein levels).

was performed by Morgan et al. using a wild-type human TCR specific for a MART-1 epitope presented by HLA-A ${ }^{\star} 0201$, and the feasibility of this approach to modify autologous $\mathrm{T}$ cells ex vivo was demonstrated (12). There were some initial signs of clinical activity with $2 / 17$ melanoma patients undergoing a partial response, and no related toxicities were observed. Subsequent studies included using TCR of mouse origin (16-20) and affinity-enhanced TCR (16, 21-23). A variety of different tumor antigen targets have also been evaluated in different tumor types (Table 1). The most advanced TCR-T clinical asset, NY-ESO-1-specific TCR-T cells, has shown particularly promising clinical responses in multiple myeloma (MM) and synovial sarcoma $(19,23,24)$, with a $61 \%$ response rate and a $38 \%$ overall survival (OS) at 3 years $(19,24,25)$ and a $91 \%$ response rate and a median OS of 3 years in MM in the context of autologous hematopoietic stem cell transplantation (HSCT) $(23,26)$. As shown in Table 1, improved clinical response rates have been observed in multiple TCR-T studies compared to the original study of Morgan et al. including complete responses, but there have also been some serious, sometimes fatal adverse events.

Early CAR-T studies, using what is now termed a firstgeneration construct design with the antigen-binding domain scFV linked to CD3 zeta or FcR $\gamma$ chain as a signaling domain, provided evidence of feasibility for CAR-T cell production but lacked clinical efficacy in $\mathrm{HIV}$-infected patients or patients with solid tumors (Table 2) (28-30, 32, 33). Indeed, activation through the CD3zeta chain or FcR $\gamma$ chain was insufficient to produce productive immunity $(43,44)$. Second-generation construct designs were developed by addition of a costimulatory domain (typically CD28 or 41BB) to CD3zeta to simultaneously provide both activation and co-stimulatory signals [several recent reviews have addressed CAR design in detail (45-49)]. The CAR-T field was truly energized when Carl June and colleagues at the University of Pennsylvania, using second generation CD19-specific CAR-T cells, achieved two complete 
TABLE 2 | Summary of some key published clinical results of CAR-gene-modified T cell therapies.

\begin{tabular}{|c|c|c|c|c|c|c|}
\hline Reference & Center & $\begin{array}{l}\text { Clinicaltrials.gov } \\
\text { identifier }\end{array}$ & Product & Indication & Outcome & Toxicity \\
\hline$(28-30)$ & $\begin{array}{l}\text { Cell Genesys } \\
\text { Inc. }\end{array}$ & $\begin{array}{l}\text { Phase I, } \\
\text { NCT01013415 }\end{array}$ & $\begin{array}{l}\text { Autol. CD4zeta-modified } \\
\text { CAR T cells }\end{array}$ & HIV-infected subjects & $\begin{array}{l}\text { Prolonged CAR T survival } \\
\text { (detectable at }>\text { decade) and } \\
\text { trafficking to infected tissues }\end{array}$ & \\
\hline$(30,31)$ & $\begin{array}{l}\text { Cell Genesys } \\
\text { Inc. }\end{array}$ & $\begin{array}{l}\text { Phase II, } \\
\text { NCT01013415 }\end{array}$ & $\begin{array}{l}\text { Autol. CD4zeta-modified } \\
\text { CAR T cells plus ART }\end{array}$ & $\begin{array}{l}\text { HIV-infected subjects } \\
\text { with undetectable } \\
\text { plasma viremia }\end{array}$ & $\begin{array}{l}\text { Prolonged CAR T survival } \\
\text { (detectable at }>\text { decade) trend } \\
\text { toward fewer patients with } \\
\text { recurrent viremia }\end{array}$ & \\
\hline (32) & $\mathrm{NCl}$ & $\begin{array}{l}\text { Phase I NCl, } \\
\text { approved by the } \\
\text { NIH IRB, NCl IRB, } \\
\text { NIH RAC, and } \\
\text { FDA-CBER }\end{array}$ & $\begin{array}{l}\text { Autol. CAR T cells specific } \\
\text { for alpha-folate receptor in } \\
\text { combination with high-dose } \\
\text { IL-2 or allogeneic PBMC }\end{array}$ & Ovarian cancer & $\begin{array}{l}\text { No reduction in tumor burden, } \\
\text { short CAR T persistence }\end{array}$ & $\begin{array}{l}\text { Mild side effects, Gr1 and } 2 \\
\text { with Gr3 and Gr4 toxicities } \\
\text { likely IL-2-related in patients } \\
\text { receiving high-dose IL-2 }\end{array}$ \\
\hline (33) & EUMC & $\begin{array}{l}\text { Phase I, approved } \\
\text { by Dutch regulatory } \\
\text { authorities }\end{array}$ & $\begin{array}{l}\text { Autol. CAR T cells } \\
\text { specific for carbonic } \\
\text { anhydrase IX }\end{array}$ & $\begin{array}{l}\text { Metastatic renal cell } \\
\text { carcinoma }\end{array}$ & PD $3 / 3$ & $\begin{array}{l}3 / 3 \text { developed Gr2-4 liver } \\
\text { toxicity likely on target } \\
\text { toxicity related to the CAR } \\
\text { T cells, } 3 / 3 \text { developed } \\
\text { HAMA to the CAR scFv } \\
\text { observed }\end{array}$ \\
\hline (34) & $\mathrm{NCl}$ & $\begin{array}{l}\text { Phase I, } \\
\text { NCT00924326 }\end{array}$ & $\begin{array}{l}\text { Autol. Murine scFv CAR } \\
\text { T cells specific for CD19 }\end{array}$ & $\begin{array}{l}\text { Advanced follicular } \\
\text { lymphoma patient } \\
\text { case report }\end{array}$ & $\begin{array}{l}\text { A durable PR lasting } \\
32 \text { weeks before progressing } \\
\text { with CD19+ disease }\end{array}$ & \\
\hline$(4,35)$ & UPenn & $\begin{array}{l}\text { Phase I, } \\
\text { NCT01029366 }\end{array}$ & $\begin{array}{l}\text { Autol. CAR T cells } \\
\text { specific for CD19 }\end{array}$ & $\begin{array}{l}\text { Advanced, chemotherapy- } \\
\text { resistant CLL }\end{array}$ & $\begin{array}{l}\text { CR } 2 / 3 \text {, PR } 1 / 3 \text {. CAR T cells } \\
\text { expanded up to } 10,000 \text { fold, } \\
\text { trafficked to the BM, and } \\
\text { persisted for }>6 \text { months in } \\
\text { the peripheral blood }\end{array}$ & $\begin{array}{l}\text { Gr3 tumor lysis syndrome } \\
\text { (1/3) patients. } 3 / 3 \\
\text { persistent B-cell aplasia }\end{array}$ \\
\hline (36) & MSKCC & $\begin{array}{l}\text { Phase I, } \\
\text { NCT00466531 } \\
\text { and NCT01044069 }\end{array}$ & $\begin{array}{l}\text { Autol. CAR T cells } \\
\text { specific for CD19 }\end{array}$ & $\begin{array}{l}\text { Patients with chemotherapy- } \\
\text { refractory CLL or relapsed } \\
\text { B-cell ALL }\end{array}$ & $\begin{array}{l}\text { CLL PR 1/8, SD 2/8, } \\
\text { ALL B-cell aplasia 1/1 }\end{array}$ & $\begin{array}{l}\text { Well tolerated, most } \\
\text { patients had rigors, } \\
\text { chills, and transient } \\
\text { fevers. } 1 \text { death from sepsis }\end{array}$ \\
\hline (5) & MSKCC & NCT01044069 & $\begin{array}{l}\text { Autol. CAR T cells } \\
\text { specific for CD19 }\end{array}$ & $\begin{array}{l}\text { Relapsed or refractory } \\
\text { B cell ALL }\end{array}$ & CR 14/16 (88\%) & $\begin{array}{l}\text { Severe CRS } 44 \% \text {, } \\
\text { CNS toxicity } 38 \%\end{array}$ \\
\hline (37) & $\begin{array}{l}\text { UPenn/ } \\
\text { CHOP }\end{array}$ & $\begin{array}{l}\text { Phase I, } \\
\text { NCT01626495 } \\
\text { and NCT01029366 }\end{array}$ & $\begin{array}{l}\text { Autol. CAR T cells } \\
\text { specific for CD19 }\end{array}$ & $\begin{array}{l}\text { Relapsed or refractory } \\
\text { ALL ( } 25 \text { pediatric, } 5 \text { adults) }\end{array}$ & CR 27/30 & $\begin{array}{l}\text { Severe CRS } 27 \% \text {, } \\
\text { CNS toxicity } 43 \%\end{array}$ \\
\hline (35) & UPenn & $\begin{array}{l}\text { Phase I, } \\
\text { NCT01029366 }\end{array}$ & $\begin{array}{l}\text { Autol. CAR T cells } \\
\text { specific for CD19 }\end{array}$ & $\begin{array}{l}\text { Relapsed or refractory } \\
\text { CLL (14 adults) }\end{array}$ & CR 4/14, PR 4/14 & $\begin{array}{l}\text { GR } 3 \text { or } 4 \text { CRS } 43 \% \text {, } \\
\text { CNS toxicity } 36 \%\end{array}$ \\
\hline (38) & $\mathrm{NCl}$ & $\begin{array}{l}\text { Phase I, } \\
\text { NCT00924326 }\end{array}$ & $\begin{array}{l}\text { Autol. Anti-CD19 } \\
\text { CAR T cells }\end{array}$ & $\begin{array}{l}\text { Advanced B-cell } \\
\text { malignancies ( } 9 \text { DLBCL, } 2 \\
\text { indolent lymphomas, and } \\
4 \text { CLL) }\end{array}$ & $\begin{array}{l}\text { CR 8/15 (DLBCL 4/7 } \\
\text { evaluable patients), } \\
\text { PR 4/15, SD 1/15, NE } 2\end{array}$ & $\begin{array}{l}\text { CRS } 1 / 15, \text { CNS } \\
\text { toxicity } 25 \%\end{array}$ \\
\hline (39) & $\mathrm{NCl}$ & $\begin{array}{l}\text { Phase I, } \\
\text { NCT01593696 }\end{array}$ & $\begin{array}{l}\text { Autol. Anti-CD19 } \\
\text { CAR T cells }\end{array}$ & $\begin{array}{l}\text { Children and young adults } \\
\text { (aged } 1-30 \text { years) with } \\
\text { relapsed or refractory } \\
\text { ALL (20) or NHL (1) }\end{array}$ & CR 14/20 ALL & $\begin{array}{l}\text { Gr3 and } 4 \text { CRS } 30 \% \text {, } \\
\text { CNS toxicity } 30 \%\end{array}$ \\
\hline (40) & FHCRC & $\begin{array}{l}\text { Phase I, } \\
\text { NCT01865617 }\end{array}$ & $\begin{array}{l}\text { Autol. Anti-CD19 } \\
\text { CAR T cells with defined } \\
\text { CD4:CD8 composition }\end{array}$ & $\begin{array}{l}\text { Adult B cell ALL after } \\
\text { lympho-depleting } \\
\text { chemotherapy }\end{array}$ & $\begin{array}{l}\text { CR: 27/30, MRD 2/30, } \\
\text { and NE 1/30 }\end{array}$ & \\
\hline$(41)$ & MCC & $\begin{array}{l}\text { Phase I, } \\
\text { NCT02348216 }\end{array}$ & $\begin{array}{l}\text { Autol. Anti-CD19 } \\
\text { CAR T cells }\end{array}$ & Refractory DLBCL & CR: $4 / 7$ & $\begin{array}{l}\text { Gr4 CRS } 1 / 7, \text { CNS toxicity } \\
\text { Gr4 1/7, and Gr3 2/7 }\end{array}$ \\
\hline$(42)$ & $\mathrm{BCM}$ & $\begin{array}{l}\text { Phase I, } \\
\text { NCT01316146 }\end{array}$ & $\begin{array}{l}\text { Autol. Anti-CD30 } \\
\text { CAR T cells }\end{array}$ & $\begin{array}{l}\text { Relapsed/refractory } \\
\text { HL or ALCL }\end{array}$ & $\begin{array}{l}\mathrm{HL} \mathrm{CR} 2 / 7, \mathrm{SD} 2 / 7 \\
\text { and ALCL CR } 1 / 2\end{array}$ & $\begin{array}{l}\text { No toxicities attributable } \\
\text { to anti-CD30 CAR T }\end{array}$ \\
\hline
\end{tabular}

ALL, acute lymphoblastic leukemia; ALCL, anaplastic large cell lymphoma; ART, anti-retroviral therapy; BCM, Baylor College of Medicine; CAR, chimeric antigen receptor; CHOP, Children's Hospital of Philadelphia; CLL, chronic lymphocytic leukemia; CNS, central nervous system; CR, complete response; CRS, cytokine release syndrome; DLBCL, diffuse large B-cell lymphoma; EUMC, Erasmus University Medical Center; FHCRC, Fred Hutchinson Cancer Research Center; G3, grade 3; G4, grade 4; HAMA, human anti-mouse antibodies; HIV, human immunodeficiency virus; HL, Hodgkin lymphoma; IL-2, interleukin 2; MCC, Moffitt Cancer Center; MRD, minimal residual disease; MSKCC, Memorial Sloan Kettering Cancer Center; NCI, National Cancer Institute; NE, non-evaluable; NHL, non-Hodgkin lymphoma; PBMC, peripheral blood mononuclear cells; PD, progressive disease; PR, partial response; UPenn, University of Pennsylvania. 
responses in the treatment of three patients with refractory advanced chronic lymphocytic leukemia (CLL) using anti-CD19 CAR T cells $(4,35)$. Subsequently, CD19 CAR-T cell therapy has generated complete and durable remissions in patients with refractory and relapsed $B$ cell malignancies $(5,6,37,50)$. As previously mentioned, the FDA has recently approved the CD19 CAR-T cell approach from Novartis, Kymriah ${ }^{\circledR}$, to treat patients with B cell ALL and the CD19 CAR-T cell approach from Kite Pharma, YESCARTA ${ }^{\mathrm{TM}}$, for the treatment of diffuse large B-cell lymphoma.

These autologous CAR-T and TCR-T cell therapies show great promise but there remain many aspects of these approaches that need to be further refined. The highly potent nature of these modified T cells produces dramatic tumor regressions; however, toxicities have also been observed. There have been a number of deaths on TCR-T and CAR-T trials. A detailed review of toxicity is beyond the scope of this review, but it is important to briefly underscore the risks. Some of these deaths have been due to apparent on target, off tumor toxicity, where expression of the target antigen on normal tissues occurs. For example, a patient died from rapid respiratory failure and multiorgan dysfunction in a CAR-T trial targeting ErbB2 in patients suffering from lung carcinoma, due to the recognition of ErbB2 on normal lung cells (51). Both Morgan et al. and Linette et al. reported instances where TCR-T targeting different MAGEA3 epitopes led to reactivity against proteins with amino acid sequence homolog to the target epitope in the brain (MAGEA12) and the heart (Titin), respectively $(20,21)$ (Table 1$)$. In various CD19 CAR-T trials, patient deaths have been reported due to neurotoxicity caused by cerebral edemas [reviewed in Ref. (52)]. Here, the exact mechanism is less clear. Other severe side effects, such as CRS and tumor lysis syndrome, can also mean that patients often require aggressive support in an intensive care unit setting (53).

Another area for improvement is to induce better efficacy in more indications. Indeed, clinical response rates and the durability of response in some hematologic malignancies and all solid tumors are currently lower than those seen with CD19 CAR-T in ALL. The tumor microenvironment in solid tumors is a hostile environment for $\mathrm{T}$ cells, and low persistence of gene-engineered $\mathrm{T}$ cells with low efficacy has been observed. Since there is a dearth of truly tumor-specific targets because most tumor-associated antigens are also naturally expressed on some normal tissues, there is a need for new targets and ways to better control "on target, off-tumor" toxicity. Additional strategies will likely be needed to improve the effectiveness of CAR-T and TCR-T in the face of these obstacles [reviewed in Ref. $(49,54)]$. In addition, the scale-up in manufacturing capability to supply thousands of patients has yet to be demonstrated and will be critical for the success of these autologous $\mathrm{T}$ cell approaches.

\section{NK Cells}

Natural killer cells are defined as $\mathrm{CD} 56^{+} \mathrm{CD} 3^{-}$cells and are innate immune lymphocytes able to exert cytotoxicity against tumor cells and virally infected cells without prior stimulation. Because of their antitumor activity, NK cells have been put forward as potential candidates for cancer immunotherapy. Cell therapy using autologous NK cells has proven to be safe and feasible when treating hematological malignancies such as CLL or different types of solid tumors but with however quite limited clinical responses (55-59).

The first evidence that allogeneic NK cells could be more cytolytic against tumor cells than autologous NK cells stems from the study by Ruggeri et al., who showed that allogeneic NK cells were very potent effectors of the GvL especially in the case of a killer-cell immunoglobulin-like receptors ligand incompatibility in the graft versus host direction in patients who received HLA-mismatched HSCT (60). In addition, the infusion of allogeneic NK cells together with interleukin (IL)-2 has shown some promising results in patients with different types of advanced cancers $(61,62)$ and several groups reported similar results using allogeneic NK cells mainly in the context of haploidentical HSCT (63-69) (Table 3). Although NK cells are short-lived, they may provide a potential off-the-shelf therapy with limited toxicity as they do not induce GvHD. A recent first-time-in-human study has also been reported exploring the use of umbilical cord blood (CB)-derived NK cells in MM (70).

A number of gene engineering cell therapy using human NK cell lines have been established. In particular, NK92 has been investigated as a therapy, either unmodified or with a variety of different genetic modifications. The first human clinical trial report using NK92 cells by Arai et al. showed some initial signs of clinical activity (73). Subsequently, a multicenter trial enrolled 15 patients, showing as well signs of clinical activity (74). Recently, clinical trials results with NK92 cells were reported by Keating and colleagues at the Princess Margaret Cancer Centre, Toronto (NCT00990717) (75). In that study, 5 of 12 patients exhibited a clinical response, including 2 complete responses, 1 of which is sustained and ongoing 10 years posttherapy. Boyiadzis et al. also recently reported results of a clinical trial of NK92 cells in 7 refractory/relapsed AML patients with 3/6 showing transient clinical responses (76).

Since NK92 cells do not express CD16 and therefore cannot mediate ADCC, a NK92 variant that has been engineered to express CD16 and intracellularly retained IL-2 (haNK) to be combined with monoclonal antibody therapies and clinical development is underway (e.g., NCT03027128). No clinical results with haNK cells have yet been reported.

Natural killer cells could also be used for the generation of CAR NK cell products for immunotherapy to enhance their effector function by providing antigen specificity. This could be especially effective in the case of cancers resistant to NK cell killing. Moreover, CAR-NK cells could be used to bridge the patient's immunity during HSCT or prior to administration of another therapy such as CAR-T cells. Preclinical studies using CAR-NK cells have shown promising results in vitro and in animal models against different types of solid tumors $(77,78)$ and hematological malignancies (79-81). Thus, first-time-in human testing is underway. Notably, Shook and colleagues at St. Judes Children's Research Hospital, Memphis, USA, have completed enrollment in a trial of CD19 CAR-expressing NK cells for B-Lineage ALL (NCT00995137), and results are 
TABLE 3 | Summary of some key published clinical results of NK cell therapies, including CAR-NK cells.

\begin{tabular}{|c|c|c|c|c|c|c|}
\hline Reference & Center & $\begin{array}{l}\text { Clinicaltrials.gov } \\
\text { identifier }\end{array}$ & Product & Indication & Outcome & Toxicity \\
\hline (60) & PUSM & Phase I, unknown & $\begin{array}{l}\text { KIR-matched or KIR- } \\
\text { mismatched allogeneic } \\
\text { NK cells }\end{array}$ & AML, ALL & $\begin{array}{l}\text { KIR-mismatch independently } \\
\text { predicted survival in AML, } \\
\text { confirming an NK-mediated } \\
\text { GvL effect }\end{array}$ & \\
\hline (61) & UMinn & $\begin{array}{l}\text { Phase I, approved by } \\
\text { the UMinn IRB and } \\
\text { conducted under } \\
\text { BB-IND } 8847\end{array}$ & $\begin{array}{l}\text { Haploidentical, related- } \\
\text { donor NK cell infusions }\end{array}$ & $\begin{array}{l}\text { Metastatic melanoma, } \\
\text { metastatic RCC, or poor- } \\
\text { prognosis AML }\end{array}$ & $\begin{array}{l}\text { Infusions after Hi-Cy/Flu } \\
\text { conditioning led to increased } \\
\text { endogenous IL-15, expansion } \\
\text { of donor NK cells, and induction } \\
\text { of complete hematologic } \\
\text { remission in } 5 \text { of } 19 \text { poor- } \\
\text { prognosis AML patients }\end{array}$ & \\
\hline (71) & UAMS & $\begin{array}{l}\text { Phase I, approved by } \\
\text { the UAMS IRB and } \\
\text { conducted under } \\
\text { BB-IND } 11347\end{array}$ & $\begin{array}{l}\text { Haploidentical, T-cell } \\
\text { depleted, KIR ligand- } \\
\text { mismatched NK cells, } \\
\text { followed by delayed } \\
\text { rescue with autologous } \\
\text { stem cells }\end{array}$ & Advanced MM & $\begin{array}{l}\text { CR 3/10, nCR 2/10, } \\
\text { MR 1/10, PR 1/10, } \\
\text { SD 1/10, and PD 2/10 }\end{array}$ & $\begin{array}{l}\text { Haploidentical NK cell infusions } \\
\text { were safe and did not impair } \\
\text { engraftment or cause GvHD }\end{array}$ \\
\hline (66) & St. Judes & $\begin{array}{l}\text { Phase I, } \\
\text { NCT00187096 }\end{array}$ & $\begin{array}{l}\text { Haploidentical } \\
\text { NK cells }\end{array}$ & AML & $\begin{array}{l}\text { All patients had transient } \\
\text { engraftment and expansion } \\
\text { of NK cells in vivo }\end{array}$ & Well tolerated \\
\hline (58) & $\mathrm{NCl}$ & $\begin{array}{l}\text { Phase I, } \\
\text { NCT00328861 }\end{array}$ & Autologous NK cells & $\begin{array}{l}\text { Metastatic } \\
\text { melanoma or RCC }\end{array}$ & $\begin{array}{l}\text { No clinical responses were } \\
\text { observed; evidence of NK cell } \\
\text { persistence but decreased } \\
\text { expression of NKG2D, and } \\
\text { lack of ex vivo cytotoxicity }\end{array}$ & \\
\hline (72) & UMinn & $\begin{array}{l}\text { Phase II, approved } \\
\text { by the UMinn IRB } \\
\text { and conducted under } \\
\text { BB-IND } 8847\end{array}$ & $\begin{array}{l}\text { Haploidentical related } \\
\text { donor NK cells }\end{array}$ & $\begin{array}{l}\text { Breast or Ovarian } \\
\text { cancer }\end{array}$ & $\begin{array}{l}\text { In vivo expansion of donor } \\
\text { NK cells failed and host Tregs } \\
\text { increased }\end{array}$ & \\
\hline (67) & UB & $\begin{array}{l}\text { Phase I, } \\
\text { NCT00799799 }\end{array}$ & $\begin{array}{l}\text { Haploidentical KIR } \\
\text { ligand-mismatched } \\
\text { NK cells }\end{array}$ & AML & $\begin{array}{l}\text { CR } 1 / 5 \text { with patients with } \\
\text { active disease. CR } 2 / 2 \\
\text { patients with a molecularly } \\
\text { relapse }\end{array}$ & $\begin{array}{l}\text { No NK cell-related toxicity, } \\
\text { including GVHD }\end{array}$ \\
\hline (73) & RUMC & $\begin{array}{l}\text { Phase I, approved } \\
\text { by the IRB and was } \\
\text { performed under an } \\
\text { FDA IND for the ex vivo } \\
\text { expansion of NK-92 } \\
\text { cells }\end{array}$ & $\begin{array}{l}\text { Allogeneic NK92 } \\
\text { cell line }\end{array}$ & $\begin{array}{l}\text { Refractory metastatic } \\
\text { RCC }(n=11) \text {; refractory } \\
\text { metastatic melanoma } \\
(n=1)\end{array}$ & $\begin{array}{l}\text { PD 10/12. Transient mixed } \\
\text { response } 1 / 12 \text {. Minor } \\
\text { response } 1 / 12\end{array}$ & $\begin{array}{l}\text { Infusional toxicities were } \\
\text { generally mild, with one grade } \\
3 \text { fever and one grade } 4 \\
\text { hypoglycemic episodes. All } \\
\text { toxicities were transient and } \\
\text { resolved }\end{array}$ \\
\hline (74) & $\begin{array}{l}\text { Multicenter } \\
\text { trial }\end{array}$ & $\begin{array}{l}\text { Phase I, study approved } \\
\text { by the ethics committee } \\
\text { at the University of } \\
\text { Frankfurt/Germany, } \\
\text { Germany }\end{array}$ & $\begin{array}{l}\text { Allogeneic NK92 } \\
\text { cell line }\end{array}$ & $\begin{array}{l}\text { Treatment-resistant } \\
\text { solid tumors/sarcomas } \\
(n=13) \text { or leukemia/ } \\
\text { lymphoma }(n=2)\end{array}$ & $\begin{array}{l}\text { MR 2/15, SD 1/15, and PD } \\
\text { 12/15. The cells persisted in } \\
\text { the recipient's circulation } \\
\text { for at least } 48 \mathrm{~h}\end{array}$ & $\begin{array}{l}\text { No infusion-related or long-term } \\
\text { side effects were observed. } \\
\text { Infusions of NK-92 cells up to } \\
10^{10} \text { cells/m2 was well tolerated }\end{array}$ \\
\hline (75) & PMCC & $\begin{array}{l}\text { Phase I, } \\
\text { NCT00990717 }\end{array}$ & $\begin{array}{l}\text { Allogeneic NK92 } \\
\text { cell line }\end{array}$ & $\begin{array}{l}\text { Lymphoma or multiple } \\
\text { myeloma patients who } \\
\text { relapsed after AHCT } \\
\text { for relapsed/refractory } \\
\text { disease }(n=12)\end{array}$ & $\begin{array}{l}5 / 12 \text { patients exhibited a } \\
\text { response, } 1 / 12 \mathrm{PR}, 2 / 12 \mathrm{CR} \text { (one } \\
\text { sustained } \mathrm{CR} \text { with patient alive } \\
10 \text { years after therapy), } \\
1 / 12 \text { transient response, } 1 / 12 \\
\text { mixed transient response }\end{array}$ & $\begin{array}{l}\text { Acute infusion-related toxicity } \\
\text { (gr1-2 fever and chills) } \\
(\mathrm{N}=4 / 12) \text { that subsided with } \\
\text { symptomatic management }\end{array}$ \\
\hline (76) & UPMC & $\begin{array}{l}\text { Phase I, } \\
\text { NCT00900809 }\end{array}$ & $\begin{array}{l}\text { Allogeneic NK92 } \\
\text { cell line }\end{array}$ & $\begin{array}{l}\text { Refractory/relapsed } \\
\operatorname{AML}(n=7)\end{array}$ & $\begin{array}{l}\text { Transient activity seen in } \\
3 \text { of } 6 \text { evaluable patients }\end{array}$ & $\begin{array}{l}\text { One patient developed grade } 2 \\
\text { fever and chills following each } \\
\text { aNK cell infusion that required } \\
\text { hospitalization; these effects } \\
\text { were reversible with supportive } \\
\text { care }\end{array}$ \\
\hline
\end{tabular}

(Continued) 
TABLE 3 | Continued

\begin{tabular}{|c|c|c|c|c|c|c|}
\hline Reference & Center & $\begin{array}{l}\text { Clinicaltrials.gov } \\
\text { identifier }\end{array}$ & Product & Indication & Outcome & Toxicity \\
\hline (62) & UAMS & $\begin{array}{l}\text { Phase I, approved by } \\
\text { the UAMS IRB and } \\
\text { conducted under } \\
\text { BB-IND } 14560\end{array}$ & $\begin{array}{l}\text { Autologous or } \\
\text { haploidentical-related } \\
\text { donor NK cells } \\
\text { expanded in culture } \\
\text { with a K562-mb15- } \\
\text { 41BBL cell line }\end{array}$ & $\begin{array}{l}\text { High-risk } \\
\text { relapsed MM }\end{array}$ & $\begin{array}{l}\text { PR } 1 / 7 \text {, significant in vivo } \\
\text { expansion associated with } \\
\text { fresh cells }\end{array}$ & No related SAE \\
\hline $\begin{array}{l}\text { Study PI: } \\
\text { David Shook }\end{array}$ & St. Judes & $\begin{array}{l}\text { Phase I, } \\
\text { NCT00995137 }\end{array}$ & $\begin{array}{l}\text { Haploidentical donor } \\
\text { NK CAR-NK }\end{array}$ & B-ALL & Data not yet reported & \\
\hline $\begin{array}{l}\text { Pl's: Poh Lin } \\
\text { Tan, Dario } \\
\text { Campana }\end{array}$ & NUHS & $\begin{array}{l}\text { Phase I, } \\
\text { NCT01974479 }\end{array}$ & $\begin{array}{l}\text { Allogeneic donor } \\
\text { CD19-CAR-NK }\end{array}$ & B-ALL & Data not yet reported & \\
\hline
\end{tabular}

AHCT, autologous hematopoietic cell transplantation; ALL, acute lymphoblastic leukemia; AML, acute myeloid leukemia; CR, complete response; GvHD, graft versus host disease; GVL, graft versus leukemia; Hi-Cy/Flu, high-dose cyclophosphamide and fludarabine; KIR, killer-cell immunoglobulin-like receptor; MDACC, M.D. Anderson Cancer Center; MM, multiple myeloma; MR, mixed response; NCI, National Cancer Institute; NUHS, National University Health System, Singapore; nCR, near complete response; PD, progressive disease; PMCC, Princess Margaret Cancer Centre, Toronto; PUSM, Perugia University School of Medicine; PR, partial response; RCC, renal cell carcinoma; RUMC, Rush University Medical Center; SAE, serious adverse event; St. Judes, St. Judes Children's Research Hospital; UAMS, University of Arkansas for Medical Sciences; UB, University of Bologna; UMinn, University of Minnesota; UPMC, University of Pittsburgh Medical Center.

awaited. The CAR used was a second-generation design with a 4-1BB costimulatory domain linked to the CD3 zeta chain. Tan, Campana and colleagues at the National University Health System in Singapore are using the identical CAR construct in an actively recruiting trial of haploidentical CD19 CAR-expressing NK cells for B-Lineage ALL (NCT01974479). The number of early clinical trials of CAR-NK is increasing year-on-year. The Chinese company PersonGen BioTherapeutics has opened four studies to enrollment in 2016, using a third-generation CAR design with the relevant scFV attached to CD28 and 41BB costimulatory domains and the CD3 zeta chain in transduced allogeneic NK92 cells. The trials are focused on different targets and indications: $\mathrm{CD}^{+}$leukemia/lymphomas in adults (NCT02742727), CD33 ${ }^{+}$myeloid malignancies in children and adults (NCT02944162), refractory CD19+ malignancies in children and adults as bridge to HSCT transplant (NCT02892695), and $\mathrm{MUC1}^{+}$solid tumors including malignant glioma of brain, colorectal carcinoma, gastric carcinoma, hepatocellular carcinoma (HCC), non-small-cell lung cancer (NSCLC), pancreatic carcinoma, and triple-negative basal-like breast carcinoma (NCT02839954). Early in 2017, Rezvani and colleagues at the MD Anderson Cancer Center, Houston, TX, USA and Bellicum Pharmaceuticals, Houston, TX, USA opened a trial of umbilical and CB-derived CAR-engineered NK cells for B lymphoid malignancies that is currently recruiting patients (NCT03056339).

Similarly, CAR-modified NK92 cells have been tested in preclinical studies and shown promising results (82-84). Consequently, several CAR-modified NK92 clinical studies are underway but currently no clinical results have been published. Overall, all the ongoing clinical trials will provide key data on safety and efficacy of gene engineering NK cell therapeutics. It will be interesting to evaluate whether NK cell therapies can be as effective as their $\mathrm{T}$ cell counterparts for certain indications and whether CAR-NK cells lead to similar adverse effects such as CRS and neurotoxicity.

\section{ClK Cells}

Cytokine-induced killer cells are a heterogeneous effector $\mathrm{CD}^{+}$ $\mathrm{CD}^{+}$cell population that exhibit non-MHC-restricted cytotoxicity [reviewed in Ref. (85)]. There has been a long history of clinical studies testing CIK cells, with evidence of antitumor effects of CIK cells against hematologic malignancies and solid tumors, along with studies exploring their antivirus potential and anti-GVHD potential. The first human clinical trial of autologous peripheral blood-derived CIK transfected to express human IL-2 by electroporation demonstrated the safety in patients with metastatic renal cell carcinoma, colorectal carcinoma, and lymphoma (86) (Table 4). In one patient with follicular lymphoma grade I, a pre-existing bone marrow involvement as the only sign of disease resolved after CIK cell therapy and was scored as a complete clinical response.

Various CIK clinical trials have combined CIK cells with other therapies, including $\mathrm{mAb}$ therapies, chemotherapies, radiotherapy, and dendritic cell (DC) therapy. An in-depth review of all CIK clinical studies is beyond the scope of this article because more than 100 clinical trials of CIK have been reported, and readers are referred to Gao et al (85), for a review (91). Some examples of key clinical studies are listed in Table 4. In 2012, a randomized phase II clinical study showed that CIK therapy could enhance the efficacy of conventional chemotherapy in patients with NSCLC (87). The study was 
TABLE 4 | Summary of some key published clinical results of CIK cell therapies.

\begin{tabular}{|c|c|c|c|c|c|c|}
\hline Reference & Center & $\begin{array}{l}\text { Clinicaltrials.gov } \\
\text { identifier }\end{array}$ & Product & Indication & Outcome & Toxicity \\
\hline (86) & HUB & & $\begin{array}{l}\text { Autologous peripheral } \\
\text { blood CIK transfected to } \\
\text { express IL-2 }\end{array}$ & $\begin{array}{l}\text { RCC, colorectal carcinoma, } \\
\text { and lymphoma }\end{array}$ & $\begin{array}{l}\text { CR 1/10, SD 3/10, } \\
\text { and PD 6/10 }\end{array}$ & $\begin{array}{l}3 / 10 \text { patients developed } \\
\text { gr2 fever that resolved the } \\
\text { next day with or without the } \\
\text { addition of antibiotics }\end{array}$ \\
\hline (87) & TMUC & $\begin{array}{l}\text { Phase II, approved by } \\
\text { the State Food and Drug } \\
\text { Administration of China } \\
\text { (2006L01023) and by the } \\
\text { ethics committee of Cancer } \\
\text { Hospital of Tianjin Medical } \\
\text { University }\end{array}$ & $\begin{array}{l}\text { Autologous CIK plus/ } \\
\text { minus chemotherapy }\end{array}$ & $\begin{array}{l}\text { NSCLC, } n=87 \\
\text { patients per } \\
\text { treatment arm }\end{array}$ & $\begin{array}{l}\text { Significantly higher 3-year OS } \\
\text { rate and median OS time in } \\
\text { CIK among early-stage } \\
\text { patients and in advanced- } \\
\text { stage patients, significantly } \\
\text { improved 3-year PFS and } \\
\text { OS rates in CIK group }\end{array}$ & Not reported \\
\hline (88) & SUSM & $\begin{array}{l}\text { Phase II, } \\
\text { NCT00699816 }\end{array}$ & Anti-CD3-activated CIK & $\operatorname{HCC}(n=230)$ & $\begin{array}{l}\text { RFS } 44 \text { months in the } \\
\text { immunotherapy group and } \\
30 \text { months in the control } \\
\text { group ( } p=0.010 \text { ) }\end{array}$ & $\begin{array}{l}\text { Significantly more AE in } \\
\text { the immunotherapy group } \\
\text { ( } p=0.002) \text {, but no significant } \\
\text { difference in the proportion } \\
\text { of patients with serious AEs } \\
\text { between groups }(p=0.15)\end{array}$ \\
\hline (89) & $\mathrm{GFCH}$ & $\begin{array}{l}\text { The study protocol } \\
\text { received ethical approval } \\
\text { from the Regional Ethics } \\
\text { Committee of Guangzhou } \\
\text { Fuda Cancer Hospital }\end{array}$ & $\begin{array}{l}\text { Autologous CIK together } \\
\text { with monocyte-derived } \\
\text { autologous DC plus } \\
\text { freeze-thawed tumor } \\
\text { lysate }\end{array}$ & $\begin{array}{l}\text { Breast cancer, } \\
\text { immunotherapy treatment } \\
\text { group, } N=188 \text { patients } \\
\text { and chemotherapy alone } \\
\text { control group, } N=180 \\
\text { patients }\end{array}$ & $\begin{array}{l}\text { DFS and OS were both } \\
\text { significantly prolonged in } \\
\text { patients in the DC-CIK } \\
\text { treatment group compared to } \\
\text { the control group }(p<0.01)\end{array}$ & $\begin{array}{l}\text { The most common AE was } \\
\text { fever in } 34.6 \% \text { of patients. } \\
\text { Information on AE grade } \\
\text { was not reported }\end{array}$ \\
\hline$(90)$ & SUSM & $\begin{array}{l}\text { Phase III, } \\
\text { NCT } 0807027\end{array}$ & $\begin{array}{l}\text { Autologous CIK plus } \\
\text { chemoradiotherapy } \\
\text { ( } n=91 \text { ) versus } \\
\text { chemoradiotherapy } \\
\text { alone }(n=89)\end{array}$ & $\begin{array}{l}\text { Newly diagnosed } \\
\text { glioblastoma }\end{array}$ & $\begin{array}{l}\text { Improved median PFS but no } \\
\text { difference in OS between the } \\
\text { CIK and control groups }\end{array}$ & $\begin{array}{l}\text { Grade } 3 \text { or higher adverse } \\
\text { events, health-related quality } \\
\text { of life and performance } \\
\text { status between the two } \\
\text { groups did not show a } \\
\text { significant difference }\end{array}$ \\
\hline
\end{tabular}

B-ALL, B-acute lymphoblastic leukemia; CB, cord blood; CIK, cytokine-induced killer cells; CR, complete response; DC, dendritic cell; GFCH, Guangzhou Fuda Cancer Hospital, China; HCC, hepatocellular carcinoma; HUB, Humboldt-Universität zu Berlin, Germany; ITT, Intention-to-treat analysis; MM, multiple myeloma; NSCLC, non-small-cell lung carcinoma; OS, overall survival; PD, partial disease; PFS, progression-free survival; RCC, renal cell carcinoma; RFS, recurrence-free survival; SD, stable disease; SUSM, Sungkyunkwan University School of Medicine, Seoul, Korea; TMUC, Tianjin Medical University Cancer Institute and Hospital, Tianjin, China.

designed to evaluate the clinical efficacy of CIK cell immunotherapy following regular chemotherapy in patients with NSCLC after surgery. Among early-stage patients, the 3-year OS rate and median OS time in the immunotherapy arm were significantly higher than those in the no immunotherapy arm. Among the advanced-stage patients, the 3-year OS rates of immunotherapy arm were significantly higher than those of the no immunotherapy arm. Lee et al. demonstrated that adjuvant immunotherapy with anti-CD3-activated CIK cells could increase the recurrence-free survival (RFS) and OS of patients with HCC (88). Patients who received CIK immunotherapy after curative treatment for HCC had a 14-month median RFS benefit compared to the no immunotherapy control group. Another recent report described results of a study comparing chemotherapy followed by CIK immunotherapy including DCs versus chemotherapy alone in stage IV breast adenocarcinoma (89). Over a 10-year period, a total of 368 patients meeting the inclusion criteria were assigned to the study groups. CIK immunotherapy consisted of monocyte-derived autologous DC plus freeze-thawed tumor lysate, with CIK prepared from non-adherent cells from the DC culture process. OS rates were significantly prolonged in patients in the DC-CIK treatment group compared with the patients in the control chemotherapy alone group. Finally, a recent phase III trial has evaluated CIK immunotherapy with radiotherapy-temozolomide (TMZ) versus TMZ alone for the treatment of newly diagnosed glioblastomas (90). A total of 180 patients were randomly assigned to the CIK immunotherapy $(n=91)$ or control group $(n=89)$. The addition of CIK cell immunotherapy to standard chemoradiotherapy with TMZ resulted in a statistically significant improvement in PFS. However, the CIK immunotherapy group did not show evidence of a beneficial effect on OS rates. Other notable studies in clinical development but yet to report clinical results are seeking to combine CIK with $\mathrm{mAb}$ anti-PD1/PDL1 strategies (NCT02886897, NCT03190811, NCT03360630, NCT03282435, and NCT03146637).

Studies have begun to explore the use of CIK cells as a CAR cell carrier. Multiple preclinical studies have demonstrated promising antitumor activity against a variety of tumors and targets [for example, Ref. (92-96)]. Formula Pharmaceuticals recently announced the opening of the first clinical trial of CAR-modified allogeneic CIK cells using its non-viral gene delivery approach (http://www.formulapharma.com/news/2017_09_18_formula_ press_release.asp). 
The next few years will see clinical results from CAR-modified NK cell and CAR-modified CIK cell trials and will determine if these approaches are efficacious and can complement or perhaps replace CAR-T/TCR-T approaches.

\section{Gamma Delta T Cells}

Gamma-delta $(\gamma \delta)$ T cells represent less than $5 \%$ of circulating $\mathrm{T}$ cells and unlike conventional $\alpha \beta$ T cells, the TCR repertoire of $\gamma \delta$ T cells is very restricted. They can be cytotoxic and secrete cytokines like conventional $\alpha \beta \mathrm{T}$ cells, but $\gamma \delta \mathrm{T}$ cells do not require MHC antigen presentation for antigen recognition. $\gamma \delta$ $\mathrm{T}$ cells are also more widely distributed in tissues throughout the body, in addition to also being present in the typical T cell compartments, the lymph nodes, and spleen, where most $\alpha \beta$ $\mathrm{T}$-cells reside. Thus, $\gamma \delta$ T cells could potentially offer differentiated activity from $\alpha \beta$ T cells, and some investigators are beginning to explore their utility as CAR carriers. Indeed, one specific subset of $\gamma \delta$ T cells identified by their expression of a $\mathrm{Vg} 9 \mathrm{Vd} 2$ TCR can be expanded using bisphosphonates and are known to recognize in an MHC-independent manner phosphoantigens, and these tend to be enriched in tumors (97). The MHCindependent nature of the $\mathrm{Vg} 9 \mathrm{Vd} 2$ antigen recognition also means that they are not alloreactive and therefore should not cause GvHD. Deniger et al. recently reported on a methodology to expand polyclonal $\gamma \delta$ T cells in vitro and electroporation with Sleeping Beauty transposon and transposase to enforce expression of a CD19 CAR (98). The demonstrated killing of CD19+ tumor cell lines and adoptive transfer of CAR $\gamma \delta \mathrm{T}$ cells reduced growth of CD19+ leukemia xenografts in mice. Clinical translation of CAR $\gamma \delta$ T cell approaches will be needed to determine if these cell carriers provide advantages over CAR $\alpha \beta \mathrm{T}$ cells. In that regard, Chen and colleagues at the Fuda Cancer Hospital, Guangzhou, China have recently opened four studies for enrollment to assess safety and efficiency of autologous peripheral blood mononuclear cell-derived $\gamma \delta \mathrm{T}$ cells against lung cancer (NCT03183232) and liver cancer (NCT03183219), breast cancer (NCT03183206), and pancreatic cancer (NCT03180437) respectively (Table 5).

\section{CELL AND GENE THERAPIES USING GENOME ENGINEERING}

A further step in simplifying supply and broadening access to donor cells is to engineer partially matched allogeneic cells. This approach is attractive for situations where dramatic clinical efficacy can be mediated rapidly and where perhaps sustained persistence of the cell product is not a requirement. One such example was recently reported whereby unmatched allogeneic donor $\mathrm{T}$ cells were lentivirally transduced to express an antiCD19 CAR, followed by gene editing with TALENs to remove expression of the endogenous TCR alpha chain to prevent GvHD together with removal of CD52 to render them insensitive to the lymphodepleting agent Alemtuzumab (99). These TCR-ablated T cells were then administered to two relapsed refractory B-acute lymphoblastic leukemia patients as temporary "bridge to transplant" designed to eradicate their leukemia before a subsequent planned allogeneic HSCT. Recently, it has also been shown that gene editing could be used to generate high numbers of redirected NY-ESO-1 T cells with a predominant stem and memory $\mathrm{T}$ cell phenotype that were tested preclinically in vitro and in a mouse model of MM without inducing GvHD (100).

The "holy grail" would be an entirely "universal donor," long-lived cell product providing an "off-the-shelf" cell therapy acceptable to any patient irrespective of their HLA and TCR specificity. Technically, genome editing technology offers the possibility to engineer such universal donor cells in a controlled manner. Cells could be modified ex vivo using gene editing to knockout expression of HLA class I and potentially HLA class II molecules to prevent GvHD that could otherwise lead to graft rejection. It has been shown that elimination of HLA class I molecules using zinc finger nucleases was possible in primary $\mathrm{T}$ cells as well as in embryonic stem cells $(101,102)$. Furthermore, the removal of HLA-A molecules in HSC had no impact on their function as the cells could engraft in immuno-compromised mice (103). Depending upon the donor cell type, the removal of other molecules such as the TCR that could induce GvHD would be required. Additionally, other cell engineering may be necessary such as the introduction of a $\beta-2$ microglobulin $(\beta-2 \mathrm{M})$ gene fusion to a non-polymorphic HLA-E, F, or G gene in order to avoid NK cell-mediated lysis of the cell product that would otherwise occur if the engineered cells are completely devoid of class I molecules $(102,104)$.

Zhao, June and colleagues have reported on preclinical studies combining lentiviral delivery of a CAR with electroporation of Cas9 mRNA and gRNAs targeting endogenous TCR, $\beta-2 \mathrm{M}$, and PD1 simultaneously, to generate gene-disrupted allogeneic CAR T cells deficient of TCR, HLA class I molecule, and PD1 by multiplex genome editing $(105,106)$. A clinical trial is planned to be undertaken at the University of Pennsylvania, University of California San Francisco, and the MD Anderson Cancer Center, USA. Lu and colleagues at Sichuan University's West China Hospital in Chengdu in China have reported the first treatment with CRISPR-modified autologous peripheral blood $\mathrm{T}$ cells

TABLE 5 | Summary of some key clinical studies evaluating gamma-delta T cell therapies.

\begin{tabular}{|c|c|c|c|c|}
\hline Center & Clinicaltrials.gov identifier & Product & Indication & Outcome \\
\hline Fuda Cancer Hospital & Phase I, NCT03183232 & Autol. PBMC-derived $\gamma \delta$ T cells & Lung cancer & Study open to enrollment \\
\hline Fuda Cancer Hospital & Phase I, NCT03183219 & Autol. PBMC-derived $\gamma \delta$ T cells & Liver cancer & Study open to enrollment \\
\hline Fuda Cancer Hospital & Phase I, NCT03183206 & Autol. PBMC-derived $\gamma \delta$ T cells & Breast cancer & Study open to enrollment \\
\hline Fuda Cancer Hospital & Phase I, NCT03180437 & Autol. PBMC-derived $\gamma \delta$ T cells & Pancreatic cancer & Study open to enrollment \\
\hline
\end{tabular}

Autol., autologous; PBMC, peripheral blood mononuclear cells; $\gamma \delta$, gamma-delta. 
in lung cancer patients that had been disrupted for PD1 using CRISPR/Cas9 (NCT02793856). These and other early studies will evaluate the safety of genome-edited $\mathrm{T}$ cells and pave the way for the more extensive multiplex genome editing required to create universal cell products.

Once clinically validated, the genome editing solutions could equally be applied to different cell types such as T cells, DCs, or HSC. However, it remains to be demonstrated that such "universal" cells could readily engraft and provide long-term protection without inducing toxicity. In addition, the less than $100 \%$ efficiency achieved for each edit will require purification of "fully edited" from "partially edited" cells, which is a significant obstacle that is yet to be resolved. There may also be unidentified molecules that may need to be edited for a cell to be truly "invisible" to the host immune system and persist for the life of the individual.

\section{CELL THERAPY TO CONTROL INFECTION}

Infections are still one of the main complications post-HSCT contributing to mortality and morbidity of the procedure.
Therefore, a lot of efforts have been dedicated in developing cell therapy approaches to control infection such as DLI as an alternative to more conventional therapies. Notably, it has been shown by several groups that the infusion of matched donorderived virus-specific $\mathrm{T}$ cells specific for cytomegalovirus, Epstein-Barr virus, or adenovirus can restore virus-specific immunity and control infection or could be used prophylactically in transplanted patients (107-114) (Table 6). In addition, the use of multivirus-specific $\mathrm{T}$ cells has also been reported to be effective in either preventing or controlling viral infection (115-118) (Table 6). However, this approach is not applicable to seronegative donors, patients undergoing immunosuppressive regimens, or for urgent use because of the time required to generate the cell product. In these specific conditions, the use of partially matched allogeneic virus-specific $\mathrm{T}$ cells has shown great promise and efficacy in controlling infection $(116,119,120)$ (Table 6), highlighting the possibility to develop banks of allogenic virus-specific T cells $(113,121)$ whereby the virus-specific $\mathrm{T}$ cells of one donor could be expanded and banked for immediate use, which could allow treating several patients with the cells from the same donor thus decreasing the cost of the therapy.

TABLE 6 | Summary of some key published clinical studies evaluating virus-specific T cell therapies.

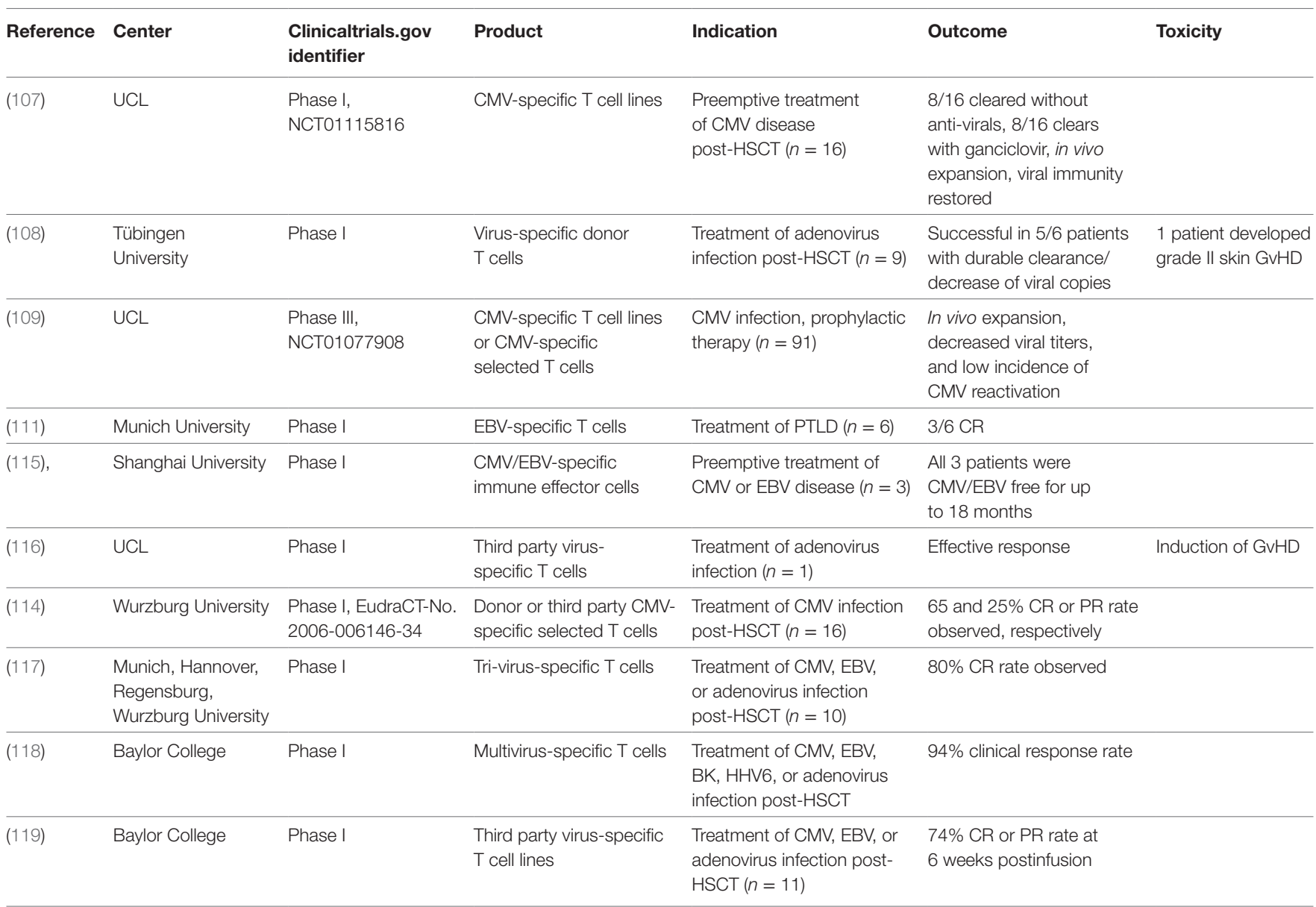

CMV, cytomegalovirus; CR, complete response; EBV, Epstein-Barr virus; GVHD, graft versus host disease; HHV6, human herpes virus 6; HSCT, hematopoietic stem cell transplantation; PR, partial response; PTLD, post-transplant lymphoproliferative disorder; UCL, University College London. 


\section{CELL AND GENE THERAPIES TO INDUCE TOLERANCE}

Several cell types are capable to regulate immune responses and thus induce tolerance. NK cells have shown to have regulatory functions aside their cytotoxic activity in the context of HSCT, impacting on acute GvHD (60). In addition, different studies suggest that a higher number of NK cells and NK cell alloreactivity might reduce GvHD development (122-124). Moreover, double negative (DN) T cells have regulatory functions and play key roles in tolerance induction post-transplantation and in autoimmune diseases $(125,126)$. DN T cells have been reported to suppress immune responses, in particular $\mathrm{T}$ cell responses and can improve allograft survival in experimental mouse models of cardiac transplantation (127). Mesenchymal stem cells (MSC) are multipotent stem cells that also have anti-inflammatory and regenerative properties. Their regulatory functions have been evaluated using in vitro and in vivo disease models (128). In addition, the infusion of autologous and allogeneic MSCs has been tested in numerous phase I studies as immunosuppressive regimen in the context of organ transplant as well as treatment for GvHD and different autoimmune diseases $(129,130)$.

Regulatory $\mathrm{T}$ cells are key players in inducing tolerance and maintaining immune homeostasis. They constitute $5-10 \%$ of
CD4 T cells in peripheral blood and are defined as $\mathrm{CD} 4^{+} \mathrm{CD} 25^{+}$ $\mathrm{CD}^{2}$ 27lowFoxP3 ${ }^{+}$(131). They have been shown to be able to regulate the functions of numerous immune cells such as CD4/ CD8 T cells, DCs, NK cells, and B cells (132). Consequently, they have been evaluated when considering a cell therapy approach to induce tolerance especially for autoimmune diseases. Treg therapies have been shown to be safe and feasible with some promising results in clinical trials using autologous Tregs for GvHD (133-136) and autoimmunity such as diabetes $(137,138)$ and Crohn's disease (139) as well as third-party allogeneic Tregs (136) (Table 7). All clinical studies have been done using polyclonal expanded Tregs; however, it has been shown that antigen-specific Tregs are more potent at suppressing undesired immune responses as compared to polyclonal Tregs. Some groups have studied the possibility to generate antigen-specific $\mathrm{T}$ cells by transferring a CAR into polyclonal expanded Tregs and showed their potency in vitro as well as in animal models (140-143). However, this approach is still to be tested clinically.

Another approach to induce tolerance could be the transfer of a chimeric autoantibody receptor (CAAR) into $\mathrm{T}$ cells to induce cytotoxicity against autoreactive T or B cells. Such an approach has demonstrated exciting results in vitro and in vivo in the case of CAAR T cells redirected against desmogelin-3 (DSG3) as a therapeutic approach for pemphigus vulgaris where

TABLE 7 | Clinical studies evaluating Tregs therapies.

\begin{tabular}{|c|c|c|c|c|c|c|}
\hline Reference & Center & $\begin{array}{l}\text { Clinicaltrials.gov } \\
\text { identifier }\end{array}$ & Product & Indication & Outcome & Toxicity \\
\hline (133) & $\begin{array}{l}\text { University of } \\
\text { Gdansk }\end{array}$ & Phase I & $\begin{array}{l}\text { Expanded donor } \\
\text { polyclonal Tregs }\end{array}$ & $\operatorname{GvHD}(n=2)$ & $\begin{array}{l}\text { Safe, decreased use of } \\
\text { immunosuppression for } \\
\text { cGvHD, temporary impact } \\
\text { on aGvHD }\end{array}$ & \\
\hline (144) & $\begin{array}{l}\text { University of } \\
\text { Minnesota }\end{array}$ & Phase I, NCT00602693 & $\begin{array}{l}\text { Expanded third-party } \\
\text { polyclonal UCB Tregs }\end{array}$ & $\operatorname{GvHD}(n=23)$ & $\begin{array}{l}\text { Reduced incidence of grade } \\
\text { II-IV aGvHD (43 versus 61\%) }\end{array}$ & $\begin{array}{l}\text { Increased incidence } \\
\text { of infection }\end{array}$ \\
\hline (134) & $\begin{array}{l}\text { University of } \\
\text { Perugia }\end{array}$ & $\begin{array}{l}\text { Phase I, Protocol No } \\
\text { 01/08 }\end{array}$ & Donor polyclonal Tregs & GvHD $(n=28)$ & $\begin{array}{l}\text { Safe, GvHD prevention } \\
\text { in the absence of } \\
\text { immunosuppression, } \\
\text { improved reconstitution }\end{array}$ & $\begin{array}{l}2 / 26 \\
\text { developed }>\text { grade } \| \\
\text { aGvHD }\end{array}$ \\
\hline (138) & San Francisco & Phase I, NCT01210664 & $\begin{array}{l}\text { Expanded autologous } \\
\text { polyclonal Tregs }\end{array}$ & Type I diabetes $(n=14)$ & $\begin{array}{l}\text { C-peptide levels persisted out } \\
\text { to } 2+\text { years after transfer in } \\
\text { several individuals, long-term } \\
\text { persistence of Tregs }\end{array}$ & \\
\hline (139) & Lille University & $\begin{array}{l}\text { Phase 1/lla, Eudract } \\
\text { no. 2006-004712-44, } \\
\text { Crohn's and Treg Cells } \\
\text { Study [CATS1] }\end{array}$ & $\begin{array}{l}\text { Ova-specific expanded } \\
\text { autologous } \operatorname{Tr} 1\end{array}$ & Crohn's disease $(n=20)$ & $\begin{array}{l}\text { Response in } 40 \%(8 / 20) \text { of } \\
\text { treated patients }\end{array}$ & \\
\hline (145) & San Francisco & Phase I, NCT02088931 & $\begin{array}{l}\text { Expanded autologous } \\
\text { polyclonal Tregs }\end{array}$ & $\begin{array}{l}\text { Kidney transplantation } \\
(n=3)\end{array}$ & Safe and well tolerated & \\
\hline
\end{tabular}

aGvHD, acute graft versus host disease; cGvHD, chronic graft versus host disease; Ova, ovalbumin; Tr1 cells, type 1 regulatory cells; Tregs, regulatory T cells. 
B cells secrete autoantibodies against DSG3, which is an antigen expressed in the skin and mucosa (146). This study showed effective killing of autoreactive cells by DSG3-CAAR T cells in vitro and in vivo while sparing keratinocytes with no off-target effects. This approach showed promising results to potentially treat autoantibody mediated immune diseases.

Numerous cell types with regulatory functions have now been tested in preclinical studies showing promising results. Further evaluation in clinical studies is warranted but these data will be key to evaluate whether gene engineering cell therapeutics could be as successful in inducing tolerance in chronic diseases as these types of approaches have been for rare diseases and oncology.

\section{CONCLUDING REMARKS}

After many years of endeavor, the field of cell and gene therapy is starting to deliver remarkable clinical benefits in some patients, particularly in certain hematological malignancies. While this is a very exciting moment for the field, more work remains to be done to further develop and optimize therapies. More relevant disease models that can help predict not only efficacy

\section{REFERENCES}

1. Hacein-Bey-Abina S, Hauer J, Lim A, Picard C, Wang GP, Berry CC, et al. Efficacy of gene therapy for X-linked severe combined immunodeficiency. N Engl J Med (2010) 363:355-64. doi:10.1056/NEJMoa1000164

2. Rama P, Matuska S, Paganoni G, Spinelli A, De Luca M, Pellegrini G. Limbal stem-cell therapy and long-term corneal regeneration. N Engl J Med (2010) 363:147-55. doi:10.1056/NEJMoa0905955

3. Gaspar HB, Cooray S, Gilmour KC, Parsley KL, Zhang F, Adams S, et al. Hematopoietic stem cell gene therapy for adenosine deaminase-deficient severe combined immunodeficiency leads to long-term immunological recovery and metabolic correction. Sci Transl Med (2011) 3:97ra80. doi:10.1126/ scitranslmed.3002716

4. Kalos M, Levine BL, Porter DL, Katz S, Grupp SA, Bagg A, et al. T cells with chimeric antigen receptors have potent antitumor effects and can establish memory in patients with advanced leukemia. Sci Transl Med (2011) 3:95ra73. doi:10.1126/scitranslmed.3002842

5. Davila ML, Riviere I, Wang X, Bartido S, Park J, Curran K, et al. Efficacy and toxicity management of $19-28 z$ CAR T cell therapy in B cell acute lymphoblastic leukemia. Sci Transl Med (2014) 6:224ra225. doi:10.1126/ scitranslmed.3008226

6. Grupp SA, Kalos M, Barrett D, Aplenc R, Porter DL, Rheingold SR, et al. Chimeric antigen receptor-modified $\mathrm{T}$ cells for acute lymphoid leukemia. N Engl J Med (2013) 368:1509-18. doi:10.1056/NEJMoa1215134

7. Rosenberg SA, Yannelli JR, Yang JC, Topalian SL, Schwartzentruber DJ, Weber JS, et al. Treatment of patients with metastatic melanoma with autologous tumor-infiltrating lymphocytes and interleukin 2. J Natl Cancer Inst (1994) 86:1159-66. doi:10.1093/jnci/86.15.1159

8. GoffSL,DudleyME, Citrin DE,Somerville RP, WunderlichJR,DanforthDN, et al. Randomized, prospective evaluation comparing intensity of lymphodepletion before adoptive transfer of tumor-infiltrating lymphocytes for patients with metastatic melanoma. J Clin Oncol (2016) 34:2389-97. doi:10.1200/JCO.2016.66.7220

9. Dembic Z, Haas W, Weiss S, Mccubrey J, Kiefer H, Von Boehmer H, et al. Transfer of specificity by murine alpha and beta T-cell receptor genes. Nature (1986) 320:232-8. doi:10.1038/320232a0

10. Clay TM, Custer MC, Sachs J, Hwu P, Rosenberg SA, Nishimura MI. Efficient transfer of a tumor antigen-reactive TCR to human peripheral blood lymphocytes confers anti-tumor reactivity. J Immunol (1999) 163:507-13. but also adverse effects are much needed. In addition, making gene engineering cell therapeutics safer is key by adding, for example, safety or kill switch to the therapy or expression control elements. As this review shows, many cell types are being explored in early clinical trials and the results of these studies will provide important insights. A major factor in realizing the potential of cell and gene therapies in large numbers of patients and in more common diseases is the efficient and cost-effective manufacturing of gene engineering cell therapeutics. Advances in automation are a key component that needs to be addressed (147). The pace of clinical development is accelerating and this means that the next few years will provide many important learnings that will hopefully translate into new therapeutic options for patients.

\section{AUTHOR CONTRIBUTIONS}

AS, LJ, and TC all contributed to write the manuscript.

\section{FUNDING}

All the authors are supported by funding from GlaxoSmithKline.

11. Schumacher TN. T-cell-receptor gene therapy. Nat Rev Immunol (2002) 2:512-9. doi:10.1038/nri841

12. Morgan RA, Dudley ME, Wunderlich JR, Hughes MS, Yang JC, Sherry RM, et al. Cancer regression in patients after transfer of genetically engineered lymphocytes. Science (2006) 314:126-9. doi:10.1126/science.1129003

13. Pinthus JH, Waks T, Kaufman-Francis K, Schindler DG, Harmelin A, Kanety $\mathrm{H}$, et al. Immuno-gene therapy of established prostate tumors using chimeric receptor-redirected human lymphocytes. Cancer Res (2003) 63:2470-6

14. June $\mathrm{CH}$, Levine BL. T cell engineering as therapy for cancer and HIV: our synthetic future. Philos Trans R Soc Lond B Biol Sci (2015) 370:20140374. doi:10.1098/rstb.2014.0374

15. Riviere I, Sadelain M. Chimeric antigen receptors: a cell and gene therapy perspective. Mol Ther (2017) 25:1117-24. doi:10.1016/j.ymthe.2017.03.034

16. Johnson LA, Morgan RA, Dudley ME, Cassard L, Yang JC, Hughes MS, et al. Gene therapy with human and mouse T-cell receptors mediates cancer regression and targets normal tissues expressing cognate antigen. Blood (2009) 114:535-46. doi:10.1182/blood-2009-03-211714

17. Davis JL, Theoret MR, Zheng Z, Lamers CH, Rosenberg SA, Morgan RA. Development of human anti-murine $\mathrm{T}$-cell receptor antibodies in both responding and nonresponding patients enrolled in TCR gene therapy trials. Clin Cancer Res (2010) 16:5852-61. doi:10.1158/1078-0432.CCR$10-1280$

18. Parkhurst MR, Yang JC, Langan RC, Dudley ME, Nathan DA, Feldman SA, et al. T cells targeting carcinoembryonic antigen can mediate regression of metastatic colorectal cancer but induce severe transient colitis. Mol Ther (2011) 19:620-6. doi:10.1038/mt.2010.272

19. Robbins PF, Morgan RA, Feldman SA, Yang JC, Sherry RM, Dudley ME, et al. Tumor regression in patients with metastatic synovial cell sarcoma and melanoma using genetically engineered lymphocytes reactive with NY-ESO-1. J Clin Oncol (2011) 29:917-24. doi:10.1200/JCO.2010.32.2537

20. Morgan RA, Chinnasamy N, Abate-Daga D, Gros A, Robbins PF, Zheng Z, et al. Cancer regression and neurological toxicity following anti-MAGE-A3 TCR gene therapy. J Immunother (2013) 36:133-51. doi:10.1097/CJI. 0b013e3182829903

21. Linette GP, Stadtmauer EA, Maus MV, Rapoport AP, Levine BL, Emery L, et al. Cardiovascular toxicity and titin cross-reactivity of affinityenhanced T cells in myeloma and melanoma. Blood (2013) 122:863-71. doi:10.1182/blood-2013-03-490565 
22. Chodon T, Comin-Anduix B, Chmielowski B, Koya RC, Wu Z, Auerbach M, et al. Adoptive transfer of MART-1 T-cell receptor transgenic lymphocytes and dendritic cell vaccination in patients with metastatic melanoma. Clin Cancer Res (2014) 20:2457-65. doi:10.1158/1078-0432. CCR-13-3017

23. Rapoport AP, Stadtmauer EA, Binder-Scholl GK, Goloubeva O, Vogl DT, Lacey SF, et al. NY-ESO-1-specific TCR-engineered T cells mediate sustained antigen-specific antitumor effects in myeloma. Nat Med (2015) 21:914-21. doi: $10.1038 / \mathrm{nm} .3910$

24. Robbins PF, Kassim SH, Tran TL, Crystal JS, Morgan RA, Feldman SA, et al. A pilot trial using lymphocytes genetically engineered with an NY-ESO-1-reactive T-cell receptor: long-term follow-up and correlates with response. Clin Cancer Res (2015) 21:1019-27. doi:10.1158/1078-0432. CCR-14-2708

25. Mackall C, D’angelo S, Grupp S, Glod J, Druta M, Chow W, et al. Open label non-randomized multi-cohort pilot study of genetically engineered NY-ESO-1 specific NY-ESO-1c259 SPEAR T-cellsTM in HLA-A*02+ patients with synovial sarcoma (NCT01343043). Ann Oncol (2016) 27:1075-1075. doi:10.1093/annonc/mdw378.29

26. Rapoport AP, Stadtmauer EA, Vogl DT, Weiss BM, Binder-Scholl GK, Brewer JE, et al. Adoptive transfer of gene-modified T-cells engineered to express high-affinity TCRs for cancer-testis antigens (CTAs) NY-ESO-1 or Lage-1, in MM patients post auto-SCT. Blood (2012) 120:472-472.

27. Kageyama S, Ikeda H, Miyahara $\mathrm{Y}$, Imai N, Ishihara M, Saito K, et al. Adoptive transfer of MAGE-A4 T-cell receptor gene-transduced lymphocytes in patients with recurrent esophageal cancer. Clin Cancer Res (2015) 21:2268-77. doi:10.1158/1078-0432.CCR-14-1559

28. Mitsuyasu RT, Anton PA, Deeks SG, Scadden DT, Connick E, Downs MT, et al. Prolonged survival and tissue trafficking following adoptive transfer of CD4zeta gene-modified autologous $\mathrm{CD} 4(+)$ and $\mathrm{CD} 8(+) \mathrm{T}$ cells in human immunodeficiency virus-infected subjects. Blood (2000) 96:785-93.

29. Walker RE, Bechtel CM, Natarajan V, Baseler M, Hege KM, Metcalf JA, et al. Long-term in vivo survival of receptor-modified syngeneic $\mathrm{T}$ cells in patients with human immunodeficiency virus infection. Blood (2000) 96:467-74.

30. Scholler J, Brady TL, Binder-Scholl G, Hwang WT, Plesa G, Hege KM, et al. Decade-long safety and function of retroviral-modified chimeric antigen receptor T cells. Sci Transl Med (2012) 4:132ra153. doi:10.1126/ scitranslmed.3003761

31. Deeks SG, Wagner B, Anton PA, Mitsuyasu RT, Scadden DT, Huang C, et al. A phase II randomized study of HIV-specific T-cell gene therapy in subjects with undetectable plasma viremia on combination antiretroviral therapy. Mol Ther (2002) 5:788-97. doi:10.1006/mthe.2002.0611

32. Kershaw MH, Westwood JA, Parker LL, Wang G, Eshhar Z, Mavroukakis SA, et al. A phase I study on adoptive immunotherapy using gene-modified $\mathrm{T}$ cells for ovarian cancer. Clin Cancer Res (2006) 12:6106-15. doi:10.1158/ 1078-0432.CCR-06-1183

33. Lamers CHJ, Sleijfer S, Vulto AG, Kruit WHJ, Kliffen M, Debets R, et al. Treatment of metastatic renal cell carcinoma with autologous T-lymphocytes genetically retargeted against carbonic anhydrase IX: first clinical experience. J Clin Oncol (2006) 24:e20-2. doi:10.1200/JCO. 2006.05.9964

34. Kochenderfer JN, Wilson WH, Janik JE, Dudley ME, Stetler-Stevenson M, Feldman SA, et al. Eradication of B-lineage cells and regression of lymphoma in a patient treated with autologous $\mathrm{T}$ cells genetically engineered to recognize CD19. Blood (2010) 116:4099-102. doi:10.1182/ blood-2010-04-281931

35. Porter DL, Levine BL, Kalos M, Bagg A, June CH. Chimeric antigen receptormodified T cells in chronic lymphoid leukemia. N Engl J Med (2011) 365: 725-33. doi:10.1056/NEJMoa1103849

36. Brentjens RJ, Riviere I, Park JH, Davila ML, Wang X, Stefanski J, et al. Safety and persistence of adoptively transferred autologous CD19-targeted $\mathrm{T}$ cells in patients with relapsed or chemotherapy refractory B-cell leukemias. Blood (2011) 118:4817-28. doi:10.1182/blood-2011-04-348540

37. Maude SL, Frey N, Shaw PA, Aplenc R, Barrett DM, Bunin NJ, et al. Chimeric antigen receptor $\mathrm{T}$ cells for sustained remissions in leukemia. N Engl J Med (2014) 371:1507-17. doi:10.1056/NEJMoa1407222
38. Kochenderfer JN, Dudley ME, Kassim SH, Somerville RP, Carpenter RO, Stetler-Stevenson M, et al. Chemotherapy-refractory diffuse large B-cell lymphoma and indolent B-cell malignancies can be effectively treated with autologous T cells expressing an anti-CD19 chimeric antigen receptor. J Clin Oncol (2015) 33:540-9. doi:10.1200/JCO.2014.56.2025

39. Lee DW, Kochenderfer JN, Stetler-Stevenson M, Cui YK, Delbrook C, Feldman SA, et al. T cells expressing CD19 chimeric antigen receptors for acute lymphoblastic leukaemia in children and young adults: a phase 1 dose-escalation trial. Lancet (2015) 385:517-28. doi:10.1016/S01406736(14)61403-3

40. Turtle CJ, Hanafi LA, Berger C, Gooley TA, Cherian S, Hudecek M, et al. CD19 CAR-T cells of defined CD4+:CD8+ composition in adult B cell ALL patients. J Clin Invest (2016) 126:2123-38. doi:10.1172/JCI85309

41. Locke FL, Neelapu SS, Bartlett NL, Siddiqi T, Chavez JC, Hosing CM, et al. Phase 1 results of ZUMA-1: a multicenter study of KTE-C19 anti-CD19 CAR T cell therapy in refractory aggressive lymphoma. Mol Ther (2017) 25:285-95. doi:10.1016/j.ymthe.2016.10.020

42. Ramos CA, Ballard B, Zhang H, Dakhova O, Gee AP, Mei Z, et al. Clinical and immunological responses after $\mathrm{CD} 30$-specific chimeric antigen receptorredirected lymphocytes. J Clin Invest (2017) 127(9):3462-71. doi:10.1172/ JCI94306

43. Brocker $\mathrm{T}$, Karjalainen $\mathrm{K}$. Signals through $\mathrm{T}$ cell receptor-zeta chain alone are insufficient to prime resting T lymphocytes. J Exp Med (1995) 181:1653-9. doi:10.1084/jem.181.5.1653

44. Brocker T. Chimeric Fv-zeta or Fv-epsilon receptors are not sufficient to induce activation or cytokine production in peripheral T cells. Blood (2000) 96:1999-2001.

45. Kochenderfer JN, Rosenberg SA. Treating B-cell cancer with $\mathrm{T}$ cells expressing anti-CD19 chimeric antigen receptors. Nat Rev Clin Oncol (2013) 10:267-76. doi:10.1038/nrclinonc.2013.46

46. Sadelain M, Brentjens R, Riviere I. The basic principles of chimeric antigen receptor design. Cancer Discov (2013) 3:388-98. doi:10.1158/2159-8290. CD-12-0548

47. June $\mathrm{CH}$, Maus MV, Plesa G, Johnson LA, Zhao Y, Levine BL, et al. Engineered T cells for cancer therapy. Cancer Immunol Immunother (2014) 63:969-75. doi:10.1007/s00262-014-1568-1

48. van der Stegen SJ, Hamieh M, Sadelain M. The pharmacology of secondgeneration chimeric antigen receptors. Nat Rev Drug Discov (2015) 14: 499-509. doi:10.1038/nrd4597

49. Johnson LA, June CH. Driving gene-engineered T cell immunotherapy of cancer. Cell Res (2017) 27:38-58. doi:10.1038/cr.2016.154

50. Brentjens RJ, Davila ML, Riviere I, Park J, Wang X, Cowell LG, et al. CD19-targeted T cells rapidly induce molecular remissions in adults with chemotherapy-refractory acute lymphoblastic leukemia. Sci Transl Med (2013) 5:177ra138. doi:10.1126/scitranslmed.3005930

51. Morgan RA, Yang JC, Kitano M, Dudley ME, Laurencot CM, Rosenberg SA. Case report of a serious adverse event following the administration of $\mathrm{T}$ cells transduced with a chimeric antigen receptor recognizing ERBB2. Mol Ther (2010) 18:843-51. doi:10.1038/mt.2010.24

52. Hartmann J, Schussler-Lenz M, Bondanza A, Buchholz CJ. Clinical development of CAR T cells-challenges and opportunities in translating innovative treatment concepts. EMBO Mol Med (2017) 9(9):1183-97. doi:10.15252/ emmm. 201607485

53. Brudno JN, Kochenderfer JN. Toxicities of chimeric antigen receptor T cells: recognition and management. Blood (2016) 127:3321-30. doi:10.1182/ blood-2016-04-703751

54. Lim WA, June $\mathrm{CH}$. The principles of engineering immune cells to treat cancer. Cell (2017) 168:724-40. doi:10.1016/j.cell.2017.01.016

55. Burns LJ, Weisdorf DJ, Defor TE, Vesole DH, Repka TL, Blazar BR, et al. IL-2based immunotherapy after autologous transplantation for lymphoma and breast cancer induces immune activation and cytokine release: a phase I/II trial. Bone Marrow Transplant (2003) 32:177-86. doi:10.1038/sj.bmt.1704086

56. Krause SW, Gastpar R, Andreesen R, Gross C, Ullrich H, Thonigs G, et al. Treatment of colon and lung cancer patients with ex vivo heat shock protein 70-peptide-activated, autologous natural killer cells: a clinical phase i trial. Clin Cancer Res (2004) 10:3699-707. doi:10.1158/1078-0432. CCR-03-0683 
57. Lundqvist A, Berg M, Smith A, Childs RW. Bortezomib treatment to potentiate the anti-tumor immunity of ex-vivo expanded adoptively infused autologous natural killer cells. J Cancer (2011) 2:383-5. doi:10.7150/ jca.2.383

58. Parkhurst MR, Riley JP, Dudley ME, Rosenberg SA. Adoptive transfer of autologous natural killer cells leads to high levels of circulating natural killer cells but does not mediate tumor regression. Clin Cancer Res (2011) 17:6287-97. doi:10.1158/1078-0432.CCR-11-1347

59. Sakamoto N, Ishikawa T, Kokura S, Okayama T, Oka K, Ideno M, et al. Phase I clinical trial of autologous NK cell therapy using novel expansion method in patients with advanced digestive cancer. J Transl Med (2015) 13:277. doi:10.1186/s12967-015-0632-8

60. Ruggeri L, Capanni M, Urbani E, Perruccio K, Shlomchik WD, Tosti A, et al. Effectiveness of donor natural killer cell alloreactivity in mismatched hematopoietic transplants. Science (2002) 295:2097-100. doi:10.1126/ science. 1068440

61. Miller JS, Soignier Y, Panoskaltsis-Mortari A, Mcnearney SA, Yun GH, Fautsch SK, et al. Successful adoptive transfer and in vivo expansion of human haploidentical NK cells in patients with cancer. Blood (2005) 105:3051-7. doi:10.1182/blood-2004-07-2974

62. Szmania S, Lapteva N, Garg T, Greenway A, Lingo J, Nair B, et al. Ex vivo-expanded natural killer cells demonstrate robust proliferation in vivo in highrisk relapsed multiple myeloma patients. J Immunother (2015) 38:24-36. doi:10.1097/CJI.0000000000000059

63. Koehl U, Sorensen J, Esser R, Zimmermann S, Gruttner HP, Tonn T, et al. IL-2 activated NK cell immunotherapy of three children after haploidentical stem cell transplantation. Blood Cells Mol Dis (2004) 33:261-6. doi:10.1016/j.bcmd.2004.08.013

64. Passweg JR, Tichelli A, Meyer-Monard S, Heim D, Stern M, Kuhne T, et al. Purified donor NK-lymphocyte infusion to consolidate engraftment after haploidentical stem cell transplantation. Leukemia (2004) 18:1835-8. doi:10.1038/sj.leu.2403524

65. Bachanova V, Burns LJ, Mckenna DH, Curtsinger J, Panoskaltsis-Mortari A, Lindgren BR, et al. Allogeneic natural killer cells for refractory lymphoma. Cancer Immunol Immunother (2010) 59:1739-44. doi:10.1007/s00262010-0896-z

66. Rubnitz JE, Inaba H, Ribeiro RC, Pounds S, Rooney B, Bell T, et al. NKAML: a pilot study to determine the safety and feasibility of haploidentical natural killer cell transplantation in childhood acute myeloid leukemia. J Clin Oncol (2010) 28:955-9. doi:10.1200/JCO.2009.24.4590

67. Curti A, Ruggeri L, D’addio A, Bontadini A, Dan E, Motta MR, et al. Successful transfer of alloreactive haploidentical KIR ligand-mismatched natural killer cells after infusion in elderly high risk acute myeloid leukemia patients. Blood (2011) 118:3273-9. doi:10.1182/blood-2011-01-329508

68. Stern M, Passweg JR, Meyer-Monard S, Esser R, Tonn T, Soerensen J, et al. Pre-emptive immunotherapy with purified natural killer cells after haploidentical SCT: a prospective phase II study in two centers. Bone Marrow Transplant (2013) 48:433-8. doi:10.1038/bmt.2012.162

69. Bachanova V, Cooley S, Defor TE, Verneris MR, Zhang B, Mckenna DH, et al. Clearance of acute myeloid leukemia by haploidentical natural killer cells is improved using IL-2 diphtheria toxin fusion protein. Blood (2014) 123:3855-63. doi:10.1182/blood-2013-10-532531

70. Shah N, Li L, Mccarty J, Kaur I, Yvon E, Shaim H, et al. Phase I study of cord blood-derived natural killer cells combined with autologous stem cell transplantation in multiple myeloma. Br J Haematol (2017) 177:457-66. doi:10.1111/bjh.14570

71. Shi J, Tricot G, Szmania S, Rosen N, Garg TK, Malaviarachchi PA, et al. Infusion of haplo-identical killer immunoglobulin-like receptor ligand mismatched NK cells for relapsed myeloma in the setting of autologous stem cell transplantation. Br J Haematol (2008) 143:641-53. doi:10.1111/j.1365-2141.2008.07340.x

72. Geller MA, Cooley S, Judson PL, Ghebre R, Carson LF, Argenta PA, et al. A phase II study of allogeneic natural killer cell therapy to treat patients with recurrent ovarian and breast cancer. Cytotherapy (2011) 13:98-107. doi:10.3109/14653249.2010.515582

73. Arai S, Meagher R, Swearingen M, Myint H, Rich E, Martinson J, et al. Infusion of the allogeneic cell line NK-92 in patients with advanced renal cell cancer or melanoma: a phase I trial. Cytotherapy (2008) 10:625-32. doi:10.1080/14653240802301872
74. Tonn T, Schwabe D, Klingemann HG, Becker S, Esser R, Koehl U, et al. Treatment of patients with advanced cancer with the natural killer cell line NK-92. Cytotherapy (2013) 15:1563-70. doi:10.1016/j.jcyt.2013.06.017

75. Williams BA, Law AD, Routy B, Denhollander N, Gupta V, Wang XH, et al. A phase I trial of NK-92 cells for refractory hematological malignancies relapsing after autologous hematopoietic cell transplantation shows safety and evidence of efficacy. Oncotarget (2017) 8:89256-68. doi:10.18632/ oncotarget.19204

76. Boyiadzis M, Agha M, Redner RL, Sehgal A, Im A, Hou JZ, et al. Phase 1 clinical trial of adoptive immunotherapy using "off-the-shelf" activated natural killer cells in patients with refractory and relapsed acute myeloid leukemia. Cytotherapy (2017) 19:1225-32. doi:10.1016/j.jcyt.2017.07.008

77. Kruschinski A, Moosmann A, Poschke I, Norell H, Chmielewski M, Seliger B, et al. Engineering antigen-specific primary human NK cells against HER-2 positive carcinomas. Proc Natl Acad Sci U S A (2008) 105:17481-6. doi:10.1073/pnas.0804788105

78. Altvater B, Landmeier S, Pscherer S, Temme J, Schweer K, Kailayangiri S, et al. 2B4 (CD244) signaling by recombinant antigen-specific chimeric receptors costimulates natural killer cell activation to leukemia and neuroblastoma cells. Clin Cancer Res (2009) 15:4857-66. doi:10.1158/1078-0432. CCR-08-2810

79. Imai C, Iwamoto S, Campana D. Genetic modification of primary natural killer cells overcomes inhibitory signals and induces specific killing of leukemic cells. Blood (2005) 106:376-83. doi:10.1182/blood-2004-12-4797

80. Muller T, Uherek C, Maki G, Chow KU, Schimpf A, Klingemann HG, et al. Expression of a CD20-specific chimeric antigen receptor enhances cytotoxic activity of NK cells and overcomes NK-resistance of lymphoma and leukemia cells. Cancer Immunol Immunother (2008) 57:411-23. doi:10.1007/ s00262-007-0383-3

81. Chu Y, Hochberg J, Yahr A, Ayello J, Van De Ven C, Barth M, et al. Targeting CD20+ aggressive B-cell non-Hodgkin lymphoma by anti-CD20 CAR mRNA-modified expanded natural killer cells in vitro and in NSG mice. Cancer Immunol Res (2015) 3:333-44. doi:10.1158/2326-6066.CIR14-0114

82. Boissel L, Betancur-Boissel M, Lu W, Krause DS, Van Etten RA, Wels WS, et al. Retargeting NK-92 cells by means of CD19- and CD20-specific chimeric antigen receptors compares favorably with antibody-dependent cellular cytotoxicity. Oncoimmunology (2013) 2:e26527. doi:10.4161/ onci. 26527

83. Klingemann H. Are natural killer cells superior CAR drivers? Oncoimmunology (2014) 3:e28147. doi:10.4161/onci.28147

84. Han J, Chu J, Keung Chan W, Zhang J, Wang Y, Cohen JB, et al. CAR-engineered NK cells targeting wild-type EGFR and EGFRvIII enhance killing of glioblastoma and patient-derived glioblastoma stem cells. Sci Rep (2015) 5:11483. doi:10.1038/srep11483

85. Gao X, Mi Y, Guo N, Xu H, Xu L, Gou X, et al. Cytokine-induced killer cells as pharmacological tools for cancer immunotherapy. Front Immunol (2017) 8:774. doi:10.3389/fimmu.2017.00774

86. Schmidt-Wolf IG, Finke S, Trojaneck B, Denkena A, Lefterova P, Schwella N, et al. Phase I clinical study applying autologous immunological effector cells transfected with the interleukin-2 gene in patients with metastatic renal cancer, colorectal cancer and lymphoma. Br J Cancer (1999) 81:1009-16. doi:10.1038/sj.bjc.6690800

87. Li R, Wang C, Liu L, Du C, Cao S, Yu J, et al. Autologous cytokineinduced killer cell immunotherapy in lung cancer: a phase II clinical study. Cancer Immunol Immunother (2012) 61:2125-33. doi:10.1007/ s00262-012-1260-2

88. Lee JH, Lee JH, Lim YS, Yeon JE, Song TJ, Yu SJ, et al. Adjuvant immunotherapy with autologous cytokine-induced killer cells for hepatocellular carcinoma. Gastroenterology (2015) 148:1383-91.e6. doi:10.1053/j.gastro. 2015.02.055

89. Lin M, Liang S, Jiang F, Xu J, Zhu W, Qian W, et al. 2003-2013, a valuable study: autologous tumor lysate-pulsed dendritic cell immunotherapy with cytokine-induced killer cells improves survival in stage IV breast cancer. Immunol Lett (2017) 183:37-43. doi:10.1016/j.imlet.2017.01.014

90. Kong DS, Nam DH, Kang SH, Lee JW, Chang JH, Kim JH, et al. Phase III randomized trial of autologous cytokine-induced killer cell immunotherapy for newly diagnosed glioblastoma in Korea. Oncotarget (2017) 8:7003-13. doi:10.18632/oncotarget.12273 
91. Guo Y, Han W. Cytokine-induced killer (CIK) cells: from basic research to clinical translation. Chin J Cancer (2015) 34:6. doi:10.1186/s40880015-0002-1

92. Schlimper C, Hombach AA, Abken H, Schmidt-Wolf IG. Improved activation toward primary colorectal cancer cells by antigen-specific targeting autologous cytokine-induced killer cells. Clin Dev Immunol (2012) 2012:238924. doi:10.1155/2012/238924

93. Hombach AA, Rappl G, Abken H. Arming cytokine-induced killer cells with chimeric antigen receptors: CD28 outperforms combined CD28-OX40 "super-stimulation". Mol Ther (2013) 21:2268-77. doi:10.1038/mt.2013.192

94. Tettamanti S, Marin V, Pizzitola I, Magnani CF, Giordano Attianese GM, Cribioli E, et al. Targeting of acute myeloid leukaemia by cytokine-induced killer cells redirected with a novel CD123-specific chimeric antigen receptor. Br J Haematol (2013) 161:389-401. doi:10.1111/bjh.12282

95. Ren X, Ma W, Lu H, Yuan L, An L, Wang X, et al. Modification of cytokine-induced killer cells with chimeric antigen receptors (CARs) enhances antitumor immunity to epidermal growth factor receptor (EGFR)-positive malignancies. Cancer Immunol Immunother (2015) 64:1517-29. doi:10.1007/ s00262-015-1757-6

96. Merker M, Pfirrmann V, Oelsner S, Fulda S, Klingebiel T, Wels WS, et al. Generation and characterization of ErbB2-CAR-engineered cytokineinduced killer cells for the treatment of high-risk soft tissue sarcoma in children. Oncotarget (2017) 8:66137-53. doi:10.18632/oncotarget.19821

97. Gober HJ, Kistowska M, Angman L, Jeno P, Mori L, De Libero G. Human $\mathrm{T}$ cell receptor gammadelta cells recognize endogenous mevalonate metabolites in tumor cells. J Exp Med (2003) 197:163-8. doi:10.1084/jem. 20021500

98. Deniger DC, Switzer K, Mi T, Maiti S, Hurton L, Singh H, et al. Bispecific T-cells expressing polyclonal repertoire of endogenous gammadelta T-cell receptors and introduced CD19-specific chimeric antigen receptor. Mol Ther (2013) 21:638-47. doi:10.1038/mt.2012.267

99. Qasim W, Zhan H, Samarasinghe S, Adams S, Amrolia P, Stafford S, et al. Molecular remission of infant B-ALL after infusion of universal TALEN gene-edited CAR T cells. Sci Transl Med (2017) 9:eaaj2013. doi:10.1126/ scitranslmed.aaj2013

100. Mastaglio S, Genovese P, Magnani Z, Ruggiero E, Landoni E, Camisa B, et al. NY-ESO-1 TCR single edited central memory and memory stem $\mathrm{T}$ cells to treat multiple myeloma without inducing GvHD. Blood (2017) 130(5):606-18. doi:10.1182/blood-2016-08-732636

101. Riolobos L, Hirata RK, Turtle CJ, Wang PR, Gornalusse GG, Zavajlevski M, et al. HLA engineering of human pluripotent stem cells. Mol Ther (2013) 21:1232-41. doi:10.1038/mt.2013.59

102. Torikai H, Reik A, Soldner F, Warren EH, Yuen C, Zhou Y, et al. Toward eliminating HLA class I expression to generate universal cells from allogeneic donors. Blood (2013) 122:1341-9. doi:10.1182/blood-2013-03-478255

103. Torikai H, Mi T, Gragert L, Maiers M, Najjar A, Ang S, et al. Genetic editing of HLA expression in hematopoietic stem cells to broaden their human application. Sci Rep (2016) 6:21757. doi:10.1038/srep21757

104. Gornalusse GG, Hirata RK, Funk SE, Riolobos L, Lopes VS, Manske G, et al. HLA-E-expressing pluripotent stem cells escape allogeneic responses and lysis by NK cells. Nat Biotechnol (2017) 35:765-72. doi:10.1038/ nbt. 3860

105. Ren J, Liu X, Fang C, Jiang S, June $\mathrm{CH}$, Zhao Y. Multiplex genome editing to generate universal CAR T cells resistant to PD1 inhibition. Clin Cancer Res (2017) 23:2255-66. doi:10.1158/1078-0432.CCR-16-1300

106. Ren J, Zhang X, Liu X, Fang C, Jiang S, June CH, et al. A versatile system for rapid multiplex genome-edited CAR T cell generation. Oncotarget (2017) 8:17002-11. doi:10.18632/oncotarget.15218

107. Peggs KS, Verfuerth S, Pizzey A, Khan N, Guiver M, Moss PA, et al. Adoptive cellular therapy for early cytomegalovirus infection after allogeneic stem-cell transplantation with virus-specific T-cell lines. Lancet (2003) 362:1375-7. doi:10.1016/S0140-6736(03)14634-X

108. Feuchtinger T, Matthes-Martin S, Richard C, Lion T, Fuhrer M, Hamprecht K, et al. Safe adoptive transfer of virus-specific T-cell immunity for the treatment of systemic adenovirus infection after allogeneic stem cell transplantation. Br J Haematol (2006) 134:64-76. doi:10.1111/j.1365-2141. 2006.06108.x
109. Mackinnon S, Thomson K, Verfuerth S, Peggs K, Lowdell M. Adoptive cellular therapy for cytomegalovirus infection following allogeneic stem cell transplantation using virus-specific T cells. Blood Cells Mol Dis (2008) 40:63-7. doi:10.1016/j.bcmd.2007.07.003

110. Heslop HE, Slobod KS, Pule MA, Hale GA, Rousseau A, Smith CA, et al. Long-term outcome of EBV-specific T-cell infusions to prevent or treat EBVrelated lymphoproliferative disease in transplant recipients. Blood (2010) 115:925-35. doi:10.1182/blood-2009-08-239186

111. Moosmann A, Bigalke I, Tischer J, Schirrmann L, Kasten J, Tippmer S, et al. Effective and long-term control of EBV PTLD after transfer of peptide-selected T cells. Blood (2010) 115:2960-70. doi:10.1182/blood2009-08-236356

112. Doubrovina E, Oflaz-Sozmen B, Prockop SE, Kernan NA, Abramson S, Teruya-Feldstein J, et al. Adoptive immunotherapy with unselected or EBV-specific T cells for biopsy-proven EBV+ lymphomas after allogeneic hematopoietic cell transplantation. Blood (2012) 119:2644-56. doi:10.1182/ blood-2011-08-371971

113. Bollard CM, Heslop HE. T cells for viral infections after allogeneic hematopoietic stem cell transplant. Blood (2016) 127:3331-40. doi:10.1182/ blood-2016-01-628982

114. Neuenhahn M, Albrecht J, Odendahl M, Schlott F, Dossinger G, Schiemann M, et al. Transfer of minimally manipulated CMV-specific $\mathrm{T}$ cells from stem cell or third-party donors to treat CMV infection after allo-HSCT. Leukemia (2017) 31(10):2161-71. doi:10.1038/leu.2017.16

115. Dong L, Gao ZY, Chang LJ, Liang Y, Tan XY, Liu JH, et al. Adoptive transfer of cytomegalovirus/Epstein-Barr virus-specific immune effector cells for therapeutic and preventive/preemptive treatment of pediatric allogeneic cell transplant recipients. J Pediatr Hematol Oncol (2010) 32:e31-7. doi:10.1097/ MPH.0b013e3181bf5e2d

116. Qasim W, Derniame S, Gilmour K, Chiesa R, Weber M, Adams S, et al. Third-party virus-specific $\mathrm{T}$ cells eradicate adenoviraemia but trigger bystander graft-versus-host disease. Br J Haematol (2011) 154:150-3. doi:10.1111/j.1365-2141.2011.08579.x

117. Gerdemann U, Katari UL, Papadopoulou A, Keirnan JM, Craddock JA, Liu $\mathrm{H}$, et al. Safety and clinical efficacy of rapidly-generated trivirusdirected T cells as treatment for adenovirus, EBV, and CMV infections after allogeneic hematopoietic stem cell transplant. Mol Ther (2013) 21:2113-21. doi:10.1038/mt.2013.151

118. Papadopoulou A, Gerdemann U, Katari UL, Tzannou I, Liu H, Martinez C, et al. Activity of broad-spectrum $\mathrm{T}$ cells as treatment for AdV, EBV, CMV, BKV, and HHV6 infections after HSCT. Sci Transl Med (2014) 6:242ra283. doi:10.1126/scitranslmed.3008825

119. Leen AM, Bollard CM, Mendizabal AM, Shpall EJ, Szabolcs P, Antin JH, et al. Multicenter study of banked third-party virus-specific T cells to treat severe viral infections after hematopoietic stem cell transplantation. Blood (2013) 121:5113-23. doi:10.1182/blood-2013-02-486324

120. Naik S, Nicholas SK, Martinez CA, Leen AM, Hanley PJ, Gottschalk SM, et al. Adoptive immunotherapy for primary immunodeficiency disorders with virus-specific T lymphocytes. J Allergy Clin Immunol (2016) 137: 1498-505.e1. doi:10.1016/j.jaci.2015.12.1311

121. O’Reilly RJ, Prockop S, Hasan AN, Koehne G, Doubrovina E. Virusspecific T-cell banks for 'off the shelf' adoptive therapy of refractory infections. Bone Marrow Transplant (2016) 51:1163-72. doi:10.1038/ bmt.2016.17

122. Asai O, Longo DL, Tian ZG, Hornung RL, Taub DD, Ruscetti FW, et al. Suppression of graft-versus-host disease and amplification of graftversus-tumor effects by activated natural killer cells after allogeneic bone marrow transplantation. JClin Invest (1998) 101:1835-42. doi:10.1172/ JCI1268

123. Lundqvist A, Mccoy JP, Samsel L, Childs R. Reduction of GVHD and enhanced antitumor effects after adoptive infusion of alloreactive Ly49mismatched NK cells from MHC-matched donors. Blood (2007) 109:3603-6. doi:10.1182/blood-2006-05-024315

124. Olson JA, Leveson-Gower DB, Gill S, Baker J, Beilhack A, Negrin RS. NK cells mediate reduction of GVHD by inhibiting activated, alloreactive T cells while retaining GVT effects. Blood (2010) 115:4293-301. doi:10.1182/ blood-2009-05-222190 
125. Zhang ZX, Yang L, Young KJ, Dutemple B, Zhang L. Identification of a previously unknown antigen-specific regulatory $\mathrm{T}$ cell and its mechanism of suppression. Nat Med (2000) 6:782-9. doi:10.1038/72303

126. Ford MS, Young KJ, Zhang Z, Ohashi PS, Zhang L. The immune regulatory function of lymphoproliferative double negative $\mathrm{T}$ cells in vitro and in vivo. J Exp Med (2002) 196:261-7. doi:10.1084/jem.20020029

127. Zhang ZX, Lian D, Huang X, Wang S, Sun H, Liu W, et al. Adoptive transfer of DNT cells induces long-term cardiac allograft survival and augments recipient CD4(+)Foxp3(+) Treg cell accumulation. Transpl Immunol (2011) 24:119-26. doi:10.1016/j.trim.2010.11.003

128. Uccelli A, Moretta L, Pistoia V. Mesenchymal stem cells in health and disease. Nat Rev Immunol (2008) 8:726-36. doi:10.1038/nri2395

129. Ghannam S, Bouffi C, Djouad F, Jorgensen C, Noel D. Immunosuppression by mesenchymal stem cells: mechanisms and clinical applications. Stem Cell Res Ther (2010) 1:2. doi:10.1186/scrt2

130. English K, Wood KJ. Mesenchymal stromal cells in transplantation rejection and tolerance. Cold Spring Harb Perspect Med (2013) 3:a015560. doi:10.1101/ cshperspect.a015560

131. Wing K, Ekmark A, Karlsson H, Rudin A, Suri-Payer E. Characterization of human CD25+ CD4+ T cells in thymus, cord and adult blood. Immunology (2002) 106:190-9. doi:10.1046/j.1365-2567.2002.01412.x

132. Schmidt A, Oberle N, Krammer PH. Molecular mechanisms of Tregmediated T cell suppression. Front Immunol (2012) 3:51. doi:10.3389/ fimmu.2012.00051

133. Trzonkowski P, Bieniaszewska M, Juscinska J, Dobyszuk A, Krzystyniak A, Marek N, et al. First-in-man clinical results of the treatment of patients with graft versus host disease with human ex vivo expanded CD4+CD25+CD127- T regulatory cells. Clin Immunol (2009) 133:22-6. doi:10.1016/j.clim.2009.06.001

134. Di Ianni M, Falzetti F, Carotti A, Terenzi A, Castellino F, Bonifacio E, et al. Tregs prevent GVHD and promote immune reconstitution in HLAhaploidentical transplantation. Blood (2011) 117:3921-8. doi:10.1182/blood2010-10-311894

135. Bacchetta R, Lucarelli B, Sartirana C, Gregori S, Lupo Stanghellini MT, Miqueu P, et al. Immunological outcome in haploidentical-HSC transplanted patients treated with IL-10-anergized donor T cells. Front Immunol (2014) 5:16. doi:10.3389/fimmu.2014.00016

136. Brunstein CG, Miller JS, Mckenna DH, Hippen KL, Defor TE, Sumstad D, et al. Umbilical cord blood-derived T regulatory cells to prevent GVHD: kinetics, toxicity profile, and clinical effect. Blood (2016) 127:1044-51. doi:10.1182/blood-2015-06-653667

137. Marek-Trzonkowska N, Mysliwiec M, Dobyszuk A, Grabowska M, Derkowska I, Juscinska J, et al. Therapy of type 1 diabetes with CD4(+) CD25(high)CD127-regulatory T cells prolongs survival of pancreatic islets results of one year follow-up. Clin Immunol (2014) 153:23-30. doi:10.1016/j. clim.2014.03.016
138. Bluestone JA, Buckner JH, Fitch M, Gitelman SE, Gupta S, Hellerstein MK, et al. Type 1 diabetes immunotherapy using polyclonal regulatory $\mathrm{T}$ cells. Sci Transl Med (2015) 7:315ra189. doi:10.1126/scitranslmed.aad4134

139. Desreumaux P, Foussat A, Allez M, Beaugerie L, Hebuterne X, Bouhnik Y, et al. Safety and efficacy of antigen-specific regulatory T-cell therapy for patients with refractory Crohn's disease. Gastroenterology (2012) 143: e1201-2. doi:10.1053/j.gastro.2012.07.116

140. Blat D, Zigmond E, Alteber Z, Waks T, Eshhar Z. Suppression of murine colitis and its associated cancer by carcinoembryonic antigen-specific regulatory T cells. Mol Ther (2014) 22:1018-28. doi:10.1038/mt.2014.41

141. Boardman DA, Philippeos C, Fruhwirth GO, Ibrahim MA, Hannen RF, Cooper D, et al. Expression of a chimeric antigen receptor specific for donor HLA class I enhances the potency of human regulatory $\mathrm{T}$ cells in preventing human skin transplant rejection. Am J Transplant (2017) 17:931-43. doi:10.1111/ajt.14185

142. Noyan F, Zimmermann K, Hardtke-Wolenski M, Knoefel A, Schulde E, Geffers R, et al. Prevention of allograft rejection by use of regulatory T cells with an MHC-specific chimeric antigen receptor. Am J Transplant (2017) 17:917-30. doi:10.1111/ajt.14175

143. Yoon J, Schmidt A, Zhang AH, Konigs C, Kim YC, Scott DW. FVIIIspecific human chimeric antigen receptor T-regulatory cells suppress T- and B-cell responses to FVIII. Blood (2017) 129:238-45. doi:10.1182/ blood-2016-07-727834

144. Brunstein CG, Miller JS, Cao Q, Mckenna DH, Hippen KL, Curtsinger J, et al. Infusion of ex vivo expanded T regulatory cells in adults transplanted with umbilical cord blood: safety profile and detection kinetics. Blood (2011) 117:1061-70. doi:10.1182/blood-2010-07-293795

145. Chandran S, Tang Q, Sarwal M, Laszik ZG, Putnam AL, Lee K, et al. Polyclonal regulatory $\mathrm{T}$ cell therapy for control of inflammation in kidney transplants. Am J Transplant (2017) 17(11):2945-54. doi:10.1111/ajt.14415

146. Ellebrecht CT, Bhoj VG, Nace A, Choi EJ, Mao X, Cho MJ, et al. Reengineering chimeric antigen receptor $\mathrm{T}$ cells for targeted therapy of autoimmune disease. Science (2016) 353:179-84. doi:10.1126/science.aaf6756

147. Mock U, Nickolay L, Philip B, Cheung GW, Zhan H, Johnston IC, et al. Automated manufacturing of chimeric antigen receptor $\mathrm{T}$ cells for adoptive immunotherapy using CliniMACS prodigy. Cytotherapy (2016) 18:1002-11. doi:10.1016/j.jcyt.2016.05.009

Conflict of Interest Statement: All authors are employee of GlaxoSmithKline.

Copyright (c) 2018 Saudemont, Jespers and Clay. This is an open-access article distributed under the terms of the Creative Commons Attribution License (CC BY). The use, distribution or reproduction in other forums is permitted, provided the original author(s) and the copyright owner are credited and that the original publication in this journal is cited, in accordance with accepted academic practice. No use, distribution or reproduction is permitted which does not comply with these terms. 